\title{
O Violão Sete Cordas no Choro Iradicional e no Choro Não
}

\section{Tradicional}

\author{
Luís Fabiano Farias Borges, Maria Alice Volpe \\ CAPES / Universidade Federal do Rio de Janeiro | Brasil
}

\begin{abstract}
Resumo: Este artigo tem como objetivo analisar a trajetória estilística do choro no Brasil sob o enfoque do violão de sete cordas. Após breve digressão sobre gênero e estilo, são discutidas modificações de ordem técnica do violão de sete cordas no choro. Considerados os maiores expoentes do instrumento no choro, Dino Sete Cordas e Rabello Raphael contribuíram para inovações estilísticas e organológicas do instrumento na segunda metade do século XX. Essas inovações são analisadas por meio da relação idiomática entre o violão de sete cordas acompanhador e solista, com base em ferramentas analíticas dos próprios músicos de choro. Diante das novas tendências do século XXI, este estudo corrobora a hipótese de que estilos tradicionais e não tradicionais coexistem pacificamente no choro.
\end{abstract}

Palavras-chave: Raphael Rabello, Dino Sete Cordas, violão de sete cordas, choro, música brasileira popular.

\begin{abstract}
This work aims to analyze the stylistic trajectory of choro music in Brazil focusing on the seven-string guitar. After a brief digression on genre and style, this article discusses the technical changes of the seven-string guitar. Considered the greatest exponents of the seven-string guitar in choro music, Dino Sete Cordas and Raphael Rabello have contributed to organological and stylistic innovations of the instrument in the second half of the 20th century. These innovations are analyzed through the idiomatic relationship between the seven-string guitar as a soloist and accompanist, based on analytical tools constructed by choro musicians. In the face of the new trends of the 21st century, this research corroborates the assumption that traditional and nontraditional styles coexist peacefully in choro music.
\end{abstract}

Keywords: Raphael Rabello, Dino Sete Cordas, sevenstring guitar, choro music, Brazilian popular music.

Este artigo é uma versão resumida, adaptada e atualizada da dissertação de mestrado apresentada ao Programa de PósGraduação Música em Contexto da Universidade de Brasília, em 20 de novembro de 2008.

The Seven-String Guitar in Traditional and Nontraditional Choro Music. Recebido em 00/00/2020. Aprovado em 00/00/2020. Disponível online: 00/00/2020. Editor 


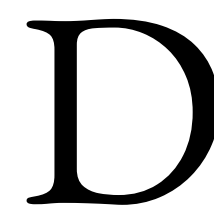
iscuteremos as inovaçóes estilísticas do violão de sete cordas ocorridas no choro durante o século XX, com o enfoque no legado de Dino Sete Cordas e de Raphael Rabello pela relação idiomática entre o violão de sete cordas acompanhador e solista. Para tanto, coloca-se o seguinte problema de pesquisa: as contribuiçóes do violão de sete cordas no choro constituem mudança musical no sentido discutido por Blacking (1977)?

Durante o longo processo histórico de confluência entre gêneros e estilos musicais no choro, o violão de sete cordas assumiu uma posição de destaque. O instrumento começou a ser difundido no Brasil a partir da década de 1920 por intermédio de China (1888-1927) e de Tute (1886-1957), consolidando-se mediante a atuação de Dino Sete Cordas (1918-2006) e de Raphael Rabello (19621995), violonistas considerados pelos choróes ${ }^{1}$ como os maiores expoentes do instrumento no choro.

O estudo do violão nas relações socioculturais brasileiras do século XIX e das primeiras décadas do século XX tem recebido a atenção de alguns especialistas (TABORDA, 2011/2019; AMORIM; WOLFF, 2019; AMORIM, 2020). No que concerne ao estudo do choro e do violão na música brasileira popular especificamente, observa-se aumento considerável de trabalhos acadêmicos e não acadêmicos nas últimas décadas (TABORDA, 1995/2004/2011; BORGES, 2008/2019; GALILEA, 2012; SOUZA, 2012; MAY, 2013; MURRAY, 2013; VALENTE, 2014; COSTA, 2015; MATEUS, 2017; SILVA NETO, 2017; NOBILE, 2018; NETO, 2019).

Nas práticas musicais do século XXI, o violão de sete cordas tem sido utilizado de forma abrangente, para além dos ambientes tradicionais do choro e do samba aos quais o instrumento está relacionado historicamente no Brasil, o que motiva o uso de terminologias como moderno, hibrido, contemporâneo, neo-choro, novo choro, pós-moderno, tradicional e não tradicional (BORGES, 2008; CLÍMACO, 2008/2011; SOUZA, 2012; VALENTE, 2014; SILVA NETO, 2017; PALOPOLI, 2018). Pode-se afirmar que essa diversidade terminológica, discutida por Palopoli (2018), revela que não há consenso na conceituação desses termos e tampouco no seu uso entre os pesquisadores e os próprios chorôes.

Adotamos a dicotomia Choro Tradicional (CT) e Choro Não Tradicional (CNT) para compreender estilo, tendo por base as contribuiçôes do violão de sete cordas. As inovaçóes trazidas por Dino e Rabello serão discutidas pelo processo de apropriação de técnicas instrumentais

\footnotetext{
${ }^{1}$ Utilizaremos a terminologia choróes para designar os músicos de choro nesta pesquisa.
} 
idiomáticas ao violão de sete cordas, junto a um processo de reelaboração de procedimentos harmônicos, melódicos, padróes figurativos de acompanhamento e de improvisação oriundos da música brasileira popular, em diálogo com outras estéticas musicais.

O estudo de musical change, retomando-se a perspectiva de Blacking (1977), justifica-se porque a música reflete significados de mudanças sociais e culturais, sendo vital para o indivíduo e a sociedade quando se enfatiza o que constitui tradição musical e o que de fato resulta em mudança musical. Ao considerar que "aquilo que é estritamente musical a respeito da mudança musical não pode ser tratado do mesmo modo que outros tipos de mudança sociocultural", busca-se "distinguir analiticamente a mudança musical de outros tipos de mudança, e também distinguir a mudança radical da variação ou inovação dentro de um sistema flexível” (BLACKING, 1977, p. 1 e 2). Nosso objeto de estudo requer especial atenção à distinção entre “inovação, aculturação e mudanças superficiais na performance musical” (BLACKING, 1977, p. 6), visto que "inovações no som musical não constituem necessariamente evidências de mudança musical” (BLACKING, 1977, p. 2). As diversas nuances da discussão conceitual de Blacking levaram-nos a perceber também a distinção entre inovações dos sistemas musicais e inovações dentro dos sistemas musicais do choro. Mudanças musicais não operam apartadas do social. Todo caso de mudança musical pressupóe um longo processo histórico e um momento crítico de mudança cognitiva, ainda que exista um período de latência no qual há um sentimento gradual dos indivíduos em direção à mudança. Nesse contexto, os performers e o seu grupo social indicam pistas para compreender a percepção do ouvinte e saber se algo está realmente mudando, motivo pelo qual devemos focar no fazer musical dos chorôes.

\section{Metodologia}

Trata-se de uma pesquisa qualitativa de natureza exploratória, o que permite familiaridade com o problema de pesquisa na tentativa de torná-lo explícito e de construir hipóteses (YIN, 2001; GIL, 2002). Para tanto, a pesquisa apresenta dois níveis analíticos:

a) ferramentas estabelecidas pelos próprios choróes a partir da harmonia funcional aplicada à música brasileira popular;

b) dicotomia baseada no Choro Tradicional (CT) e no Choro Não Tradicional (CNT) para 
compreender estilo.

As fontes de pesquisa compreendem nove entrevistas em primeira mão, biografias, registros fonográficos, transcrições próprias e de terceiros, artigos acadêmicos e não acadêmicos. O repertório da pesquisa foi selecionado por amostragem, a partir de obras que marcaram a carreira dos choróes desde a década de 1920 .

\section{Revisão de Literatura: a confluência de gêneros populares no choro}

As raízes do choro são comumente atribuídas à classe média urbana carioca da segunda metade do século XIX. O violão foi bastante requisitado na música popular nesse período, durante o qual o choro pode ser compreendido como uma maneira de interpretar gêneros populares europeus que se estabeleciam no Brasil. Nesse contexto, os conjuntos de pau e corda $a^{2}$ foram essenciais para as bases constitutivas do choro com fulcro na tradição oral e performática (BORGES, 2019, p. 2).

Na segunda metade do século XIX, as práticas improvisatórias da música popular conviveram com a música escrita no Brasil, com destaque para as publicações de partituras para piano. As publicaçốes atraíam pianistas amadores, consumidores ávidos por polcas, tangos, valsas, lundus, mazurcas e schottisches (BORGES, 2019, p. 3). Esses gêneros musicais, compreendidos como danças do choro (BRAGA, 2004), foram apropriados ao longo do século XX por intermédio de arranjos dos regionais de choro. Esses regionais originaram-se na década de 1930 e foram indispensáveis para a trajetória estilística do choro, cuja instrumentação passou a inserir também o pandeiro, além dos tradicionais instrumentos utilizados desde os conjuntos de pau e corda. A instrumentação dos regionais de choro da década de 1930 ainda está presente nas rodas de choro do século XXI, as quais são caracterizadas pelos encontros informais e convidativos a músicos de diversos estilos.

Lima (2006) sugere que os elementos constitutivos do choro remontam ao estilo barroco. Para tanto, Lima reporta-se ao período colonial brasileiro para explicar a preferência pelo baixo cantante no estabelecimento dos gêneros musicais ao longo do século XIX, o que viria posteriormente a consolidar o choro. Kiefer (1977, p. 15) argumenta que o baixo cantante funciona como uma segunda melodia, além de dialogar com a melodia principal. Com efeito, o baixo cantante é um dos elementos

\footnotetext{
${ }^{2}$ Grupos de música popular formados por flauta, cavaquinho e violão.
} 
característicos da tradição do choro e foi reelaborado com a inserção do violão de sete cordas ao longo do século XX.

Ao analisar a obra de Joaquim Antônio Callado da Silva Júnior (1848-1880), Chiquinha Gonzaga (1847-1935) e Ernesto Nazareth (1863-1934), Verzoni (2000, p. 131-137) concluiu que esses compositores não utilizaram o subtítulo choro para designar gênero em suas músicas ao longo do século XIX. Ainda que a palavra choro tenha sido utilizada em diversos contextos no século XIX, os subtítulos das partituras desses compositores reportavam-se a outros gêneros, tais como tango brasileiro $^{3}$, polca, polca-lundu e valsa, o que Braga (2004) define como as danças do choro.

O primeiro registro da palavra choro em contexto musical formal foi feito no tango Só no Choro, música que Chiquinha Gonzaga dedicou a Henrique Alves de Mesquita em 1889 (VERZONI, 2000, p. 125). O momento de inflexão nas partituras impressas teria ocorrido por volta da década de 1920, ensejando um processo de substituição de gêneros musicais em virtude da adaptação aos novos tempos e à nova moda de caráter mercadológico. A década de 1920, portanto, pode ser situada como o período em que o choro se consolidou como gênero no Brasil. ${ }^{4}$

O choro concebido como gênero não está relacionado apenas à maneira de tocar, mas sim a padrões estabelecidos com base em um repertório consagrado. Em contrapartida, a maneira pela qual o choro costuma ser compreendido como estilo depende da performance, pois a maneira de tocar o choro é parte integrante e indissociável do estilo musical. Por exemplo, além das tradicionais danças do choro, obras do repertório clássico ou até mesmo do rock $^{5}$ podem integrar-se ao repertório do choro na condição de estilo.

Ao perquirir os conceitos de gênero e estilo com base na enciclopédia alemã Die Musik in

\footnotetext{
${ }^{3}$ José Paulo Becker (entrevista concedida, 2008) diz que pensa em maxixe ou choro quando toca tango brasileiro. Portanto, não estabelece grandes distinçôes entre tango brasileiro e choro.

${ }^{4}$ No livro O Melhor de Pixinguinha (1997), o subtítulo choro aparece (32 vezes), polca (2 vezes) e maxixe (3 vezes). Há também terminologias que se referem à fusão de gêneros, tais como: chorinho-maxixe (p. 8), polca-choro (p. 32 e 34) e samba-choro (p. 62, 72 e 80).

${ }^{5}$ O registro fonográfico Beatles N' Choro (Deckdisc, 2003), produzido pelo cavaquinista Henrique Cazes, é um exemplo de repertório adaptado ao choro por meio de músicas dos Beatles. Cazes (2003) diz: "Neste segundo trabalho de tradução chorística da música dos Beatles, procurei abrir o leque de possibilidades através de uma aproximação com os gêneros que formaram o Choro. Lundu (I Want to Hold your Hand), polca (Martha my Dear), habanera (Michelle), maxixes, choros, sambas e até o um maracatu compõem um largo espectro de possibilidades rítmicas que se casam, de forma espantosamente natural, com os temas originais. Balança, lirismo e humor” (CAZES, 2003).
} 
Geschichte und Gegenwart (MGG) ${ }^{6}$, Verzoni (2000, p. 27) identifica a existência da complexa relação entre gênero e estilo. Enquanto gênero musical se configura de modo indissociável de função social, muitas vezes também associado a determinadas formas e características musicais, estilo é compreendido pelas particularidades estruturais de cada componente musical integradas "ao modo de articular os gestos musicais" (MOORE, 2001, p. 441). ${ }^{7}$

Convencionalmente, a discussão de estilo em musicologia considera os elementos estruturais, tais como fraseologia musical, padrões rítmicos e melódicos, formas, texturas, várias dimensóes relacionadas à harmonia, como tipos de acorde e progressóes. Estudos mais recentes têm considerado propriedades organológicas e possibilidades idiomáticas de determinados instrumentos na constituição de estilo. Apenas para citar um dos estudos referenciais sobre desenvolvimento de estilo musical que assume as possibilidades técnicas instrumentais como fator determinante na conformação de um novo estilo, Rowland (1992) demonstra o surgimento de novos padróes de textura (idiomática do instrumento), cuja conformação de um novo estilo acaba por definir um gênero. ${ }^{8}$

Diante da complexidade conceitual de gênero e de estilo, Taborda (2010) propóe uma periodização do choro a partir dos registros fonográficos como fonte, em vez da tradicional perspectiva cronológica. A partir de sua proposta de classificação de estilos do choro, os marcos seriam: terno de pau e corda (de 1902 a 1920), o Choro Carioca (primeiro modelo de variaçóes e contracantos), a organização e a sonoridade do Regional de Benedito Lacerda, as gravações de Pixiguinha e Benedito com seu regional (1946), Jacob do Bandolim e Radamés Gnattali.

\footnotetext{
${ }^{6}$ Blume (MGG, 1965, vol. 12p. 1303), in verbis: "Der Stil einer Komposition ist eine unterschiedliche Eigenschaft, die die Eigenart der Krâfte, welche eine Musik gestaltet haben, darstellt".

${ }^{7}$ Franco Fabbri (1982) recorre à conceituação de gênero musical por meio da integração da semiótica à sociologia. Embora tenhamos preocupaçôes de natureza sociológica, esclarecemos que o campo conceitual proposto por Fabbri (1982) não é central neste estudo porque não adotamos o campo teórico da semiótica.

8 "Em meados de 1790, houve como que uma revolução da técnica pianística. A princípio, o uso de pedal começa a surgir com vários tipos de pedalização com o intuito de criar algum tipo de efeito para imitar outro instrumento. No entanto, os compositores perceberam que o pedal abria possibilidades de novas texturas que não eram possíveis em instrumentos de tecla anteriores. Um recurso particularmente favorecido foi o das texturas de acompanhamento da mão esquerda, que excedessem 9o ou 10o (e.g. Baixo de Alberti e outros acompanhamentos). Muitos compositores franceses e ingleses tomaram partido desse recurso e, por volta de 1800, surgiu uma larga proporção de repertório para teclado [...]. Esse novo estilo claramente teve um apelo imenso para compositores na França e na Inglaterra, no início do século XIX" (ROWLAND, 1992, p. 39-40; tradução nossa).
} 


\section{Discussão: Choro Tradicional versus Choro não Tradicional}

Algumas inovações no choro foram incorporadas sistemicamente de modo a serem reconhecidas como uma vertente não tradicional. De outro modo, algumas propostas configuram experimentaçốes localizadas, mas que não foram adotadas amplamente pelos chorôes. O termo neochoro proposto por Tárik de Souza (1998) e adotado por Zagury $(2005 ; 2014)$ para referir-se a grupos que surgiram no Rio de Janeiro a partir da década de 1990 (como o Trio Madeira Brasil, Rabo de Lagartixa, Água de Moringa e Tira Poeira) aplica-se a uma geração posterior àquela que abordamos neste estudo como não tradicional. Após estabelecer diferenças entre as categorias tradicional e moderno, Clímaco (2008, p. 368-369) remete à “terceira coisa” como “um gênero acentuadamente híbrido, que evidencia de forma marcante caracteristicas de estilo individuais e um afastamento grande das características de estilo do gênero". Consideramos essa "terceira coisa" como o desdobramento do choro moderno pelo que englobamos ambas as categorias sob o termo não tradicional.

O longo e contínuo processo de formação dos chorôes permite afirmar que a dicotomia Choro Tradicional (CT) e Choro Não Tradicional (CNT) não implica a rejeição ou a total substituição do CT pelo CNT. Trata-se do apontamento de características estilísticas marcantes, pois a própria formação dos chorôes tradicionais e não tradicionais é consolidada pelas rodas de choro diante de um convívio salutar (BORGES, 2008).

Canclini (2003, p. 196) assevera que o tradicional e o moderno podem combinar-se, quase sem conflitos, quando a exaltação à tradição se limita à cultura, mas recomenda cautela com relação ao uso deliberado do termo hibridismo. Com relação ao hibridismo na música, Aragão (2001, p. 40) revela um posicionamento análogo em sua análise dos arranjos desenvolvidos por Pixinguinha na década de 1930 e argumenta que a euforia em torno do hibridismo pode perder de vista que culturas são híbridas de uma maneira ou de outra.

Blacking (1977, p. 22) enfatiza a necessidade de estudos que diferenciem uma mudança musical de outros tipos de mudanças ocorridas na sociedade, visto que mudanças sociais estão relacionadas com aquelas que operam nos sistemas culturais. As mudanças consistem em uma ampla variação da estrutura da organização sociocultural, de modo que não devem ser caracterizadas por um caráter 
transitório. Essas mudanças devem ser analisadas com cautela porque não é qualquer acumulação de novos sons que determina uma mudança musical. Muitos casos tidos como mudança musical seriam mudança social ou menor variação no estilo musical. Para Blacking (1973, p. 54), a música apenas confirma o que está presente na sociedade e na cultura.

Béhague (1973, p. 211) afirma que o samba permaneceu praticamente sem mudanças musicais até o surgimento da bossa nova, de modo que o samba teria revolucionado a cena da música popular brasileira em 1958, apesar das recorrentes críticas com relação à influência do jazz. O pesquisador interpreta essas mudanças estilísticas como um processo natural, motivado pela modernização econômica por meio da qual passava o Brasil. O período teria gerado autoconfiança e orgulho nacional a ponto de poder gerar (ainda que inconscientemente) um intercâmbio cultural equiparado com o resto do mundo.

As perspectivas sobre mudança musical motivaram a utilização da dicotomia CT e CNT, uma vez que as dissonâncias não diferenciam necessariamente o CT do CNT, mas ajudam avaliar características marcantes entre os choróes (BORGES, 2008). Carvalho (1992, p. 95) argumenta que o campo conceitual de Blacking está fundamentado na coerência interna de uma tradição musical e na hipótese de que as categorias nativas sobre música podem ser compatíveis com as categorias analíticas. Não se trata de assumir apenas as categorias nativas, mas sim de considerar que os praticantes de certas tradições podem ser analistas de sua própria música. No caso do choro, a coerência interna pode ser observada pela construção das próprias ferramentas analíticas que os choróes elaboram para analisar o próprio repertório.

\subsection{Ferramentas analíticas dos chorões: análise harmônica e improvisação}

Esta seção discute algumas ferramentas analíticas que constituem a base dos chorões. Primeiramente, é comum observar a modulação típica no CT, cuja estrutura segue a forma rondó ABACA: A (tonalidade maior), B (relativo) e C (subdominante) ou A (tonalidade menor), B (relativo) e C (homônimo). No fim dessas seçốes, existem cadências recorrentes (similares ao turnaround do jazz) as quais podem ser entendidas como volteio harmônico, tanto no CT quanto no CNT (BORGES, 2008b). A relação entre tônica (T) e dominante (D) pode ser expandida para os 
graus I-VI-II-V, incluindo variaçốes por meio do subV ${ }^{7}$, acordes maiores e menores ${ }^{9}$. No entanto, é necessário observar a melodia original do choro para que as notas dos acordes não entrem em conflito com a melodia.

Os choróes antigos elaboravam suas próprias ferramentas analíticas para analisar o próprio repertório, mesmo sem ter necessariamente o ensino formalizado de música. Uma representação emblemática do pragmatismo dos chorôes antigos é encontrada nos métodos práticos para violão e bandolim da segunda metade do século XX. A nomenclatura é baseada na expectativa da ocorrência dos acordes, razão pela qual utilizam terminologias como primeira do tom, segunda do tom e assim por diante (CARNEIRO, 2001; BORGES, 2008).

De forma análoga, José de Alencar Soares (1951-2011) - conhecido como Alencar Sete Cordas - desenvolveu a Árvore Harmônica. Trata-se de uma teoria que consiste na análise de caminhos harmônicos com base no treinamento auditivo. Alencar Sete Cordas (entrevista concedida, 2007) argumenta que "é necessário analisar a probabilidade de ocorrência dos acordes para poder concatená-los em distintos contextos harmônicos”"10.

$\mathrm{Na}$ tonalidade maior, a estrutura harmônica da Árvore Harmônica considera que uma música pode se desenvolver por cima (IV) ou por baixo (IIm). Essa nomenclatura corresponde, respectivamente, à terceira do tom e à terceira menor dos choróes antigos. Em tonalidade menor, a estrutura básica da Árvore Harmônica consiste no caminho harmônico pelo IV grau menor. A tonalidade maior é representada em $a$ (estrutura básica) e em $b$ (estrutura ampliada). A tonalidade menor é disposta em $c$ (estrutura básica) e em $d$ (estrutura ampliada), conforme Figura 1:

\footnotetext{
${ }^{9}$ Chediak (1986, p.85) diz que o sub $\mathrm{V}^{7}$ (comumente associado ao acorde napolitano) é “o acorde substituto do $\mathrm{V}^{7}$ com a fundamental uma quarta aumentada abaixo. $\mathrm{O}$ sub $\mathrm{V}^{7}$ é encontrado um semitom acima do acorde onde vai resolver”. ${ }^{10}$ Alencar Sete Cordas (entrevista concedida, 2007) discorre sobre como os choróes pensam em música e menciona Dino Sete Cordas e Raphael Rabello com admiração (BORGES, 2019, p. 80).
} 
FIGURA 1 - Árvore Harmônica.

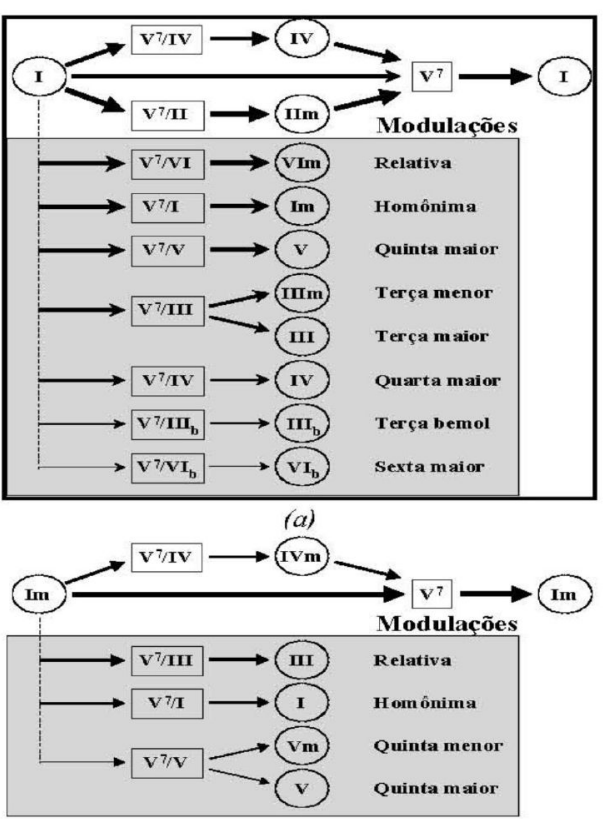

(c)

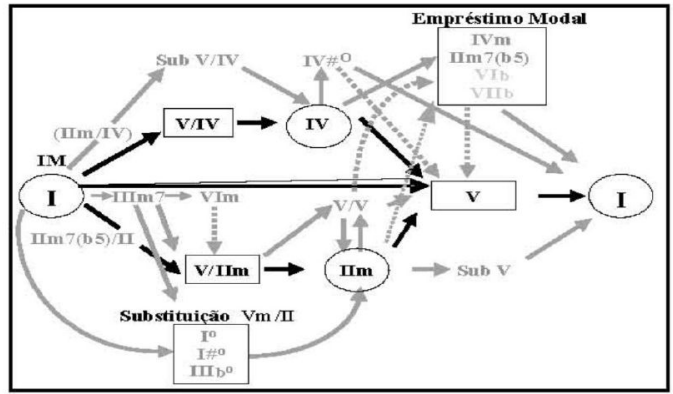

(b)

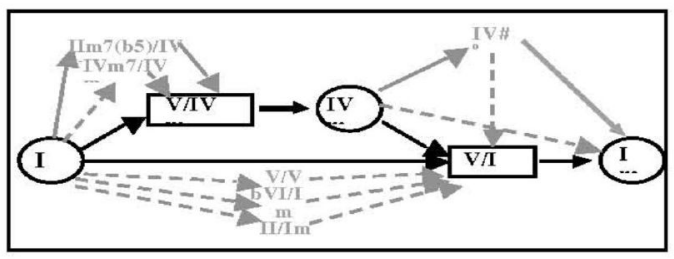

(d)

Fonte: FERNEDA et al. (2008).

De forma subsidiária à Árvore Harmônica, a Tabela 1 sugere outras expectativas dos choros com base na curva tonal:

TABELA 1 - Curva tonal em tonalidade maior.

\begin{tabular}{|c|c|c|}
\hline & Harmonia & Expectativa \\
\hline 1) & $\begin{array}{l}\text { Dominante individual do IIm } \\
\text { (corresponde à terceira menor dos chorôes antigos e ao } \\
\text { caminho por baixo da Árvore Harmônica) }\end{array}$ & Ocorre geralmente no início da seção A \\
\hline 2) & $\begin{array}{l}\text { Dominante individual do IV grau } \\
\text { (corresponde à terceira do tom dos chorôes antigos e ao } \\
\text { caminho por cima da Árvore Harmônica) }\end{array}$ & Idem \\
\hline 3) & $\mathrm{V}^{7}$ of $\mathrm{V}^{7}$ & $\begin{array}{l}\text { É comum na seção } \mathrm{A} \text { ou em seções cujo } \\
\text { período musical seja precedido pela cadência } \\
\mathrm{V}^{7} / \mathrm{Vim}\end{array}$ \\
\hline & $\mathrm{IVm}$ & $\begin{array}{l}\text { Ocorre de duas formas: no início da música, } \\
\text { após a passagem pelo IV com o intuito de } \\
\text { retornar à tônica. A segunda forma ocorre no } \\
\text { fim das músicas (passagem do primeiro grau } \\
\text { para o IV menor sem preparação) }\end{array}$ \\
\hline & bIII & $\begin{array}{l}\text { Ocorre, geralmente, por meio de uma melodia } \\
\text { transposta do tom principal. Para tanto, há } \\
\text { uma preparação feita por } \mathrm{IIm} / \mathrm{V}^{7} \text { ou IIm7 } \\
\text { (b5) } / \mathrm{V}^{7}\end{array}$ \\
\hline & III & $\begin{array}{l}\text { Há uma breve ruptura harmônica mediante } \\
\text { um novo material melódico não muito longo, } \\
\text { com uma preparação análoga ao bIII }\end{array}$ \\
\hline
\end{tabular}


TABELA 1 - (cont.) Curva tonal em tonalidade maior.

\begin{tabular}{|c|c|c|}
\hline & Harmonia & Expectativa \\
\hline & V grau maior & Idem \\
\hline & Passagens cromáticas & $\begin{array}{l}\text { Condução de baixos cromáticos em } \\
\text { movimento ascendente ou descendente, } \\
\text { possibilitando melodias sinuosas e não } \\
\text { diatônicas }\end{array}$ \\
\hline & $\mathrm{SubV}^{7}$ & $\begin{array}{l}\text { a) No desenvolvimento da seção musical } \\
\text { b) Nos volteios harmônicos } \\
\text { (elemento estilístico não tradicional) }\end{array}$ \\
\hline
\end{tabular}

Fonte: BORGES (2008, p. 45).

Os números 1 e 2 da Tabela 1 são recorrentes no CT. Os números 3 e 4, por sua vez, tratam dos acordes não diatônicos e dos caminhos harmônicos menos triviais do que os dos números 1 e 2. Os números 5, 6 e 7 abordam graus da escala mais afastados. Vejamos a seguir exemplos práticos com base nos compositores do CT.

Entre as famosas composições do Pixinguinha (1897-1973) em duas seções, destacam-se Lamento (1928) e Carinhoso (1923). Trata-se de dois choros pertencentes à tradição do choro, embora apresentem certa complexidade harmônica e melódica, bem como modulações para graus da escala mais afastados. A seção A do choro Lamento (em Ré maior), por exemplo, exemplifica o número 6 da Tabela 1, conforme Figura 2:

FIGURA 2 - Lamento (Pixinguinha). Compassos 12-14.

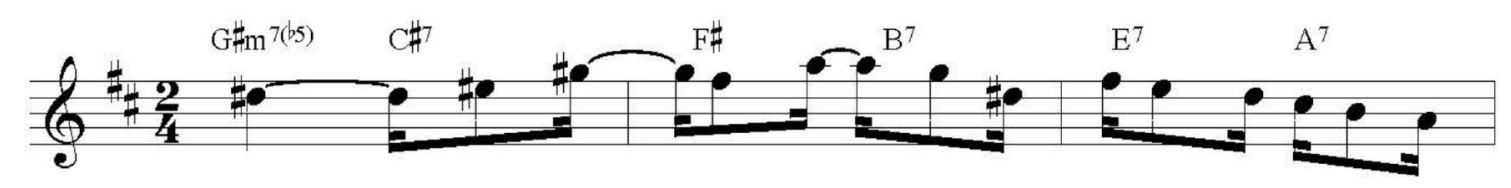

Fonte: CARRASQUEIRA (1997, p. 56).

Nesse tipo de estudo dos choróes, a harmonia por cifras é essencial. Guerreiro (2006) argumenta que as cifras numéricas colocadas abaixo da linha do contínuo foram substituídas pelas cifras de origem norte-americana na prática atual dos músicos. Essa substituição teria sido introduzida no 
Brasil por Radamés Gnattali (1906-1988) durante a década de $1930^{11}$, em cujo período Pixinguinha compartilhou os arranjos com Radamés Gnattali na Orquestra Victor Brasileira. ${ }^{12}$

O estudo da harmonia por cifras é indissociável da improvisação, apresentando ferramentas consolidadas na literatura como a teoria da escala de acordes (FARIA, 1991; CHEDIAK, 1986). Entretanto, essa teoria é mais adequada ao CNT, pois requer escalas específicas para cada acorde mediante frases que exigem novos materiais melódicos, aproximando-se da improvisação no jazz. Contudo, no CT, é comum haver mudanças melódicas pontuais no improviso sem gerar necessariamente um material novo, desconectado da linha melódica principal. Nesse contexto, entre as cinco categorias de improvisação analisadas por Kernfeld (2006), destacam-se duas para o CT: improvisação por fórmulas (disfarça fórmulas prontas e evita clichês) e improvisação motívica (evita repetições óbvias do material musical).

Há estudos que analisam a relação entre o choro e o jazz. Valente (2014) sugere que houve mudanças substanciais na improvisação do choro por meio de conceitos provenientes da improvisação no jazz. Ao comparar as práticas musicais do choro no século XX e XXI, a autora diz que o gênero foi expandido e define essa nova fase como choro contemporâneo. Ao tratar da improvisação no choro, Korman (2004) argumenta que o solista elabora melodias mediante virtuosas variações, enquanto outros músicos improvisam o contraponto e o acompanhamento.

Com relação às influências do jazz no violão de sete cordas do choro, Silva Neto (2017, p. 105) argumenta que o violonista Rogério Caetano recorre a elementos não tradicionais da linguagem do choro, agregando elementos de outras linguagens musicais, como jazz, blues e rock. O autor analisa as inovações do violão de sete cordas sob a perspectiva da hibridação, considerando as influências de Dino e Raphael Rabello sobre o violão de Rogério Caetano.

\subsection{Idiomatismo do violão de sete cordas}

Idiomatismo é um conjunto de potencialidades inerentes a cada instrumento musical

\footnotetext{
${ }^{11} \mathrm{Na}$ era do rádio, a música popular era tocada tanto por orquestras quanto por regionais de choro. Destacam-se dois regionais nesse período: Regional de Benedito Lacerda (1934) e o Regional do Canboto (1951).

${ }^{12}$ Guerreiro (2006) discorre sobre a influência dos livros de orquestração escritos nos EUA no Brasil, durante a primeira metade do século XX. Ao mencionar depoimentos de César Guerra-Peixe, Guerreiro salienta que a cifra foi introduzida no Brasil por Radamés Gnattali na década de 1930.
} 
(BORGES, 2008). No caso do violão, Lima (2006) argumenta que o idiomatismo foi adotado pelos violonistas por intermédio das inversóes de acordes e da escrita idiomática em partituras, como forma de compensar as limitações estruturais do instrumento.

Nos regionais de choro, o violão de sete cordas desempenha função análoga à do violão de seis cordas. Todavia, devido à extensão do instrumento na região grave, o violão de sete cordas cumpre com maior desenvoltura a tarefa de dialogar com a melodia principal. No violão de sete cordas do choro, o idiomatismo é indissociável das baixarias e da organologia, conforme será tratado adiante.

É provável que o violão de sete cordas tenha origens russas, anteriores ao século XX. No choro, foram os vestígios do instrumento em uma comunidade russa de ciganos no Rio de Janeiro que permitiram seu estabelecimento durante a década de 1920 por China (1888-1927), irmão mais velho de Pixinguinha, e Tute (1886-1957). Com base em depoimentos de Pixinguinha, sabe-se que esses ciganos se estabeleceram na Praça Onze e mantiveram contato com a chamada Pequena África, onde se consolidou o samba urbano carioca (BORGES, 2008; SILVA NETO, 2017).

Os primeiros registros do violão de sete cordas no Brasil provêm dos acompanhamentos de China, principalmente por sua atuação no grupo Os Oito Batutas na década de 1920. Nos registros fonográficos por meio mecânico, observa-se um encadeamento harmônico simples na linha do baixo se comparado ao de violonistas de gerações posteriores. Convém acessar os fonogramas da fase elétrica de gravação (1927), pois estão presentes os fundamentos que são adotados pelos violonistas de sete cordas até os dias atuais (TABORDA, 1995; BORGES, 2008).

Desde a década de 1930, os acompanhamentos de Tute atestam que dissonâncias pontuais não são suficientes para descaracterizar um CT. Na música Dançando com Lágrimas nos Olhos (Lamartine Babo/Joe Burke), por exemplo, Tute utiliza um acorde com quinta aumentada em uma simples cadência harmônica: D / B7 / E7 / A7(\#5). Desde esse período, os violóes preenchiam a harmonia, movimentando os baixos numa progressão modulante, o que quebrava a monotonia da repetição de notas. A harmonização de Tute enriqueceu-se pelo uso eventual de acorde diminuto de passagem a partir de 1930. Seu acompanhamento recorre com maior frequência às segundas e às terceiras inversões dos acordes na condução da linha do baixo (TABORDA, 1995; BORGES, 2008).

As baixarias do choro podem ser compreendidas como uma forma típica de acompanhamento 
polimelódico ${ }^{13}$ no violão, ou seja, melodias independentes que costumam aparecer na região grave do instrumento. No estilo tradicional, é comum executá-las com o auxílio de uma dedeira ${ }^{14}$ no polegar da mão direita. Para obter sonoridade idiomática ao choro, é imprescindível buscar a articulação adequada de ligados ${ }^{15}$ e de cordas soltas ${ }^{16}$. Há diversas possibilidades de articular as baixarias por meio dos ligados, mas todas devem refletir fluidez no fraseado.

As baixarias costumam ser improvisadas, mas também podem ser preconcebidas. Em muitas ocasiões, o fraseado das baixarias anuncia a mudança de seções musicais ou o retorno ao tema. $\mathrm{Na}$ execução das baixarias, há a utilização sistemática do polegar da mão direita mediante a técnica violonística conhecida como apoio. Nesse contexto, Maurício Carrilho (entrevista concedida, 2008b) argumenta que o violonista de choro possui um punch especial que o distingue de violonistas de outros gêneros. Além disso, Carrilho (2008b) salienta que o uso da sétima corda afinada em Dó não se firmou em decorrência das tonalidades comuns aos choros. A sétima corda teria se consolidado com a afinação em Dó pela ausência de uma corda que sustentasse a nota Si com sonoridade, tensão e afinação adequadas.

\subsection{Dino Sete Cordas: o violão de sete cordas de acompanhamento}

Horondino José da Silva (1918-2006), conhecido como Dino Sete Cordas, iniciou sua carreira na década de 1930, no Regional de Benedito Lacerda. Contudo, começou a tocar o violão de sete cordas após cerca de três décadas de o instrumento ter sido adotado por China e Tute no Brasil. Os acompanhamentos de Dino inauguraram um novo discurso musical no violão de sete cordas por meio da condução da linha do baixo na segunda metade do século XX. Esse discurso fundamentou-se na reinvenção de frases inspiradas em Pixinguinha, cujos aspectos técnicos foram analisados por Taborda de forma pormenorizada (1995). ${ }^{17}$

\footnotetext{
${ }^{13}$ Braga (2004, p. 35) propõe a terminologia acompanhamento polimelódico.

${ }^{14}$ Dedeira é um anel com ponta de aço ou de plástico colocado na ponta do dedo polegar da mão direita.

${ }^{15}$ Os ligados consistem na técnica de tocar uma nota apenas uma vez com a ação da mão direita, ligando-a a outra nota pela ação de algum dedo da mão esquerda.

${ }^{16} \mathrm{Na}$ afinação tradicional, as cordas soltas do violão equivalem a: E, B, G, D, A, E.

${ }^{17}$ Taborda (1995) propóe uma divisão da obra de Dino em duas fases. Antes de Pixinguinha, Dino expressou-se dentro da linguagem estabelecida à época sem grandes diferenças se comparado aos violóes e Nei Orestes e Carlos Lentine. A segunda fase consiste no período em que é caracterizado pelo contato com Pixinguinha na década de 1950.
} 
Mesmo quando atuava em apresentaçôes populares de grandes proporçóes, Dino recorria a recursos que possibilitassem a utilização do instrumento acústico. Para isso, Dino utilizava todas as cordas de aço (em vez de cordas de tripa) durante a fase inicial de sua carreira, o que viabilizou sua performance até mesmo sem amplificação do instrumento.

Na década de 1960, o violão de Dino passou a apresentar uma sonoridade seca e de curta duração, tendo em vista a adaptação da quarta corda de violoncelo no lugar da sétima corda do violão. As duas primeiras cordas mais agudas (em náilon) contrapunham-se a uma robusta terceira corda de aço, possibilitando uma sonoridade mais suave no conjunto do seu instrumento. Trata-se de uma inovação organológica que combina cordas de náilon, aço e violoncelo no violão (BORGES, 2008). Essa inovação contribuiu para o estabelecimento de uma sonoridade característica do violão de sete cordas tradicional nos acompanhamentos dos regionais de choro até os dias atuais, o que Braga (2004) define como violão típico.

Nos padróes de frase, Dino preenchia os prolongamentos da linha melódica do solista com as baixarias, estabelecendo uma relação coesa entre o baixo do violão e a melodia principal. As dissonâncias dos acompanhamentos de Dino tornaram-se mais frequentes se comparadas às do antecessor Tute. Ademais, Dino passou a utilizar com mais frequência o acorde m7(b5), que costumava aparecer como substituto do II grau menor. ${ }^{18}$

No álbum Vibraçôes (RCA, 1967), Dino gravou a música Ingênuo (Pixinguinha) com o grupo Época de Ouro. Trata-se de um choro emblemático em Fá maior, que apresenta caminhos melódicos e harmônicos pouco comuns à época. As ferramentas analíticas estabelecidas pelos chorões antigos não são suficientes para analisar esse complexo choro, ainda que Pixinguinha seja um chorão tradicional. No compasso 16, por exemplo, o tema principal de Ingênuo parece transposto no bIII grau (Lá bemol maior $)^{19}$, conforme caracterização do número 5 da Tabela 1 . Uma forma possível de explicar como os chorôes compreendem a seção A de Ingênuo é por meio da harmonia funcional aplicada à música popular, conforme trecho a seguir:

\footnotetext{
${ }^{18}$ Alencar Sete Cordas (entrevista concedida, 2007) ressaltou que Dino utiliza o modo dórico, mesmo sem conhecer os modos utilizados na improvisação de jazz.

${ }^{19}$ A Tabela 1 (Curva tonal) sugere que a modulą̧ão passageira para o bIII requer a melodia principal transposta quase literalmente. No famoso choro Homenagem à Velha Guarda (Sivuca), há uma modulação para o bIII, mantendo-se o material melódico assim como ocorre em Ingênuo.
} 
TABELA 2 - Ingênuo (Pixiguinha) seção A.

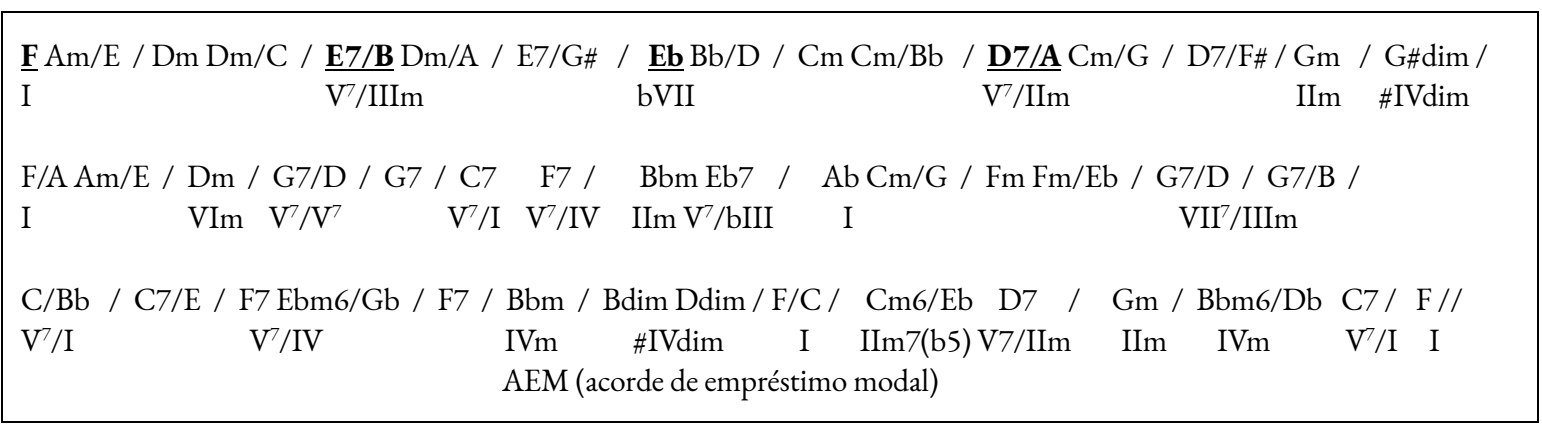

Fonte: BORGES (2008, p. 79).

$\mathrm{Na}$ versão original de Pixinguinha (RCA Victor, 1947), ouvimos apenas os acordes cuja cifra está sublinhada e negritada acima. Sendo assim, os acordes iniciais de Ingênuo podem ser compreendidos da seguinte maneira: F / E7 / Eb / D7 (Tabela 1, número 8). Na versão gravada em 1967, porém, Dino enriqueceu a harmonia original, visto que os acordes Am (IIIm, Dr) e Dm (VIm, Tr) foram inseridos pela condução da linha do baixo, conforme Figura 3:

FIGURA 3 - Linha do baixo de Dino Sete Cordas.

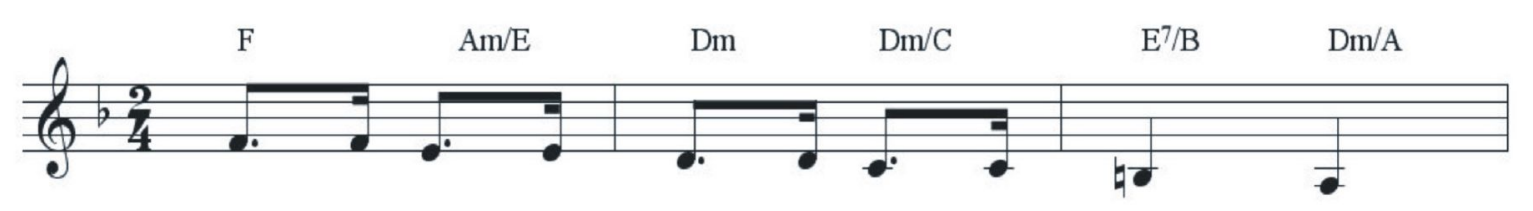

Fonte: BRAGA (2004, p. 86).

Dino utiliza o mesmo padrão melódico das baixarias em diferentes trechos de Ingênuo, cujo recurso é comum nos estudos dos chorões. Costuma-se utilizar o mesmo padrão melódico da baixaria em distintos lugares do braço do instrumento em razão do idiomatismo. Uma vez memorizada a frase, os chorôes são capazes de replicá-la em distintos contextos musicais. $\mathrm{Na}$ Figura 4, há uma análise intervalar da frase sobre o acorde 7(b9), a qual Dino utiliza em três momentos da seção A de Ingênuo: ${ }^{20}$

\footnotetext{
${ }^{20}$ Dino utiliza esse padrão melódico sobre o arpejo 7(b9) nos compassos 8, 12 e 24 (BRAGA, 2004, p. 86).
} 
FIGURA 4 - Padrão melódico de uma baixaria de Dino inserida em Ingênuo (Pixinguinha).

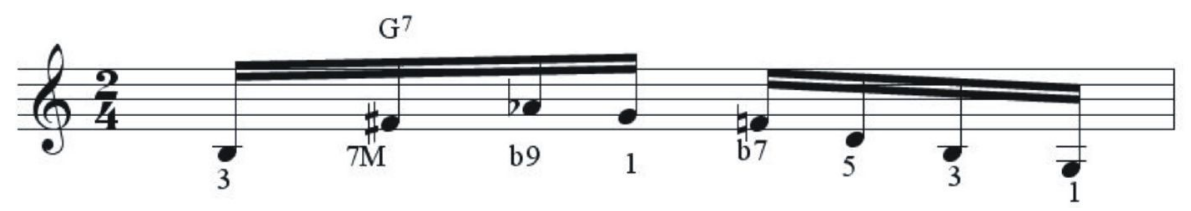

Fonte: BORGES (2019, p. 26).

A busca por caminhos harmônicos inesperados é algo comum no choro, tanto em composições quanto em arranjos. Luciana Rabello (entrevista concedida, 2008) argumenta que as surpresas enriquecem o choro. Nesse contexto, Dino recorria eventualmente à escala de tons inteiros como elemento surpresa, como na música Cuidado, Violão (José Toledo), gravada no álbum Choros Imortais (EMI, vol. 1, 1964). Em Ingênuo, Dino também utiliza a escala de tons inteiros na transição da seção A para a B, conforme Figura $5::^{21}$

FIGURA 5 - Frase de Dino no fim da seção A. Compassos 35-36.

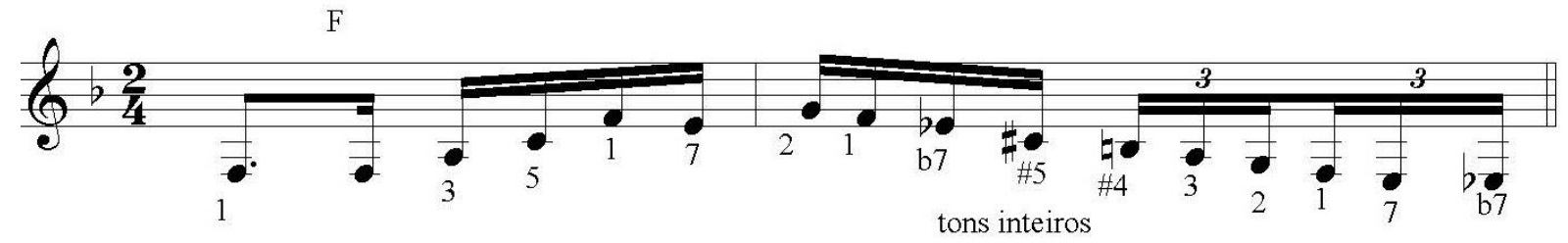

Fonte: BRAGA (2004, p. 86).

Dino notabilizou-se também pelos virtuosos fraseados em escala descendente. Na seção B do choro Cinco Companheiros, Dino utiliza uma baixaria com figuras em fusas:

FIGURA 6 - Linha do baixo de Dino em Fá maior.

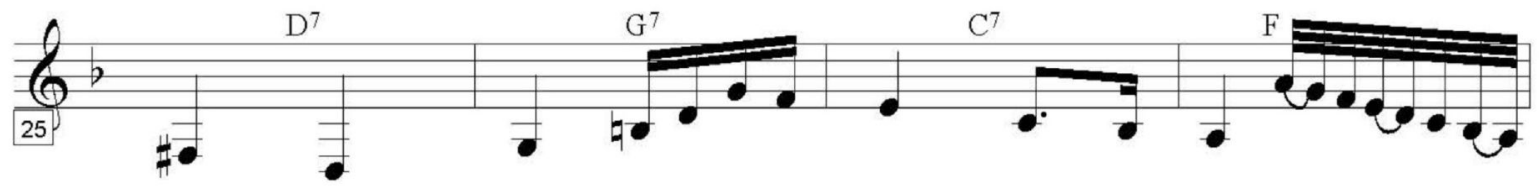

Fonte: BORGES (2008, p. 94).

\footnotetext{
${ }^{21}$ As escalas diminuta, cromática e de tons inteiros são definidas como escalas simétricas (FARIA, 1991, p. 55).
} 
Outro elemento idiomático do violão de sete cordas consiste nas conduções rítmicas, conhecidas como levadas pelos violonistas populares. Nesse sentido, destaca-se o violáo tamborim por meio do qual Dino utiliza pizzicato e uma sonoridade percussiva, conforme Figura $7:^{22}$

FIGURA 7- Violão tamborim de Dino.

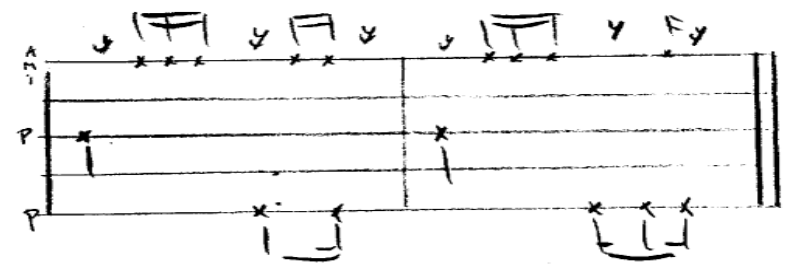

Fonte: TABORDA (1995, p. 70).

Com Dino Sete Cordas, as baixarias foram enriquecidas por variados padrões rítmicos. Combinadas com quiálteras e fusas, as figuras sincopadas de Dino possibilitaram a consolidação de um violão de sete cordas virtuosístico nos acompanhamentos do choro. Todavia, as inovaçóes musicais de Dino não se devem apenas ao virtuosismo do acompanhamento, pois é necessário considerar a inflexão de todo o fraseado. Seus acompanhamentos originais cumpriam bem a função de uma segunda linha melódica, em constante diálogo com a melodia principal. Outra inovação do violão de sete cordas de Dino foi sua presença em diversas instrumentações, até mesmo em duos.

Diante do exposto, a Figura 8 visa sintetizar alguns padróes rítmicos dos acompanhamentos de Dino Sete Cordas:

FIGURA 8 - Padrões rítmicos de Dino.

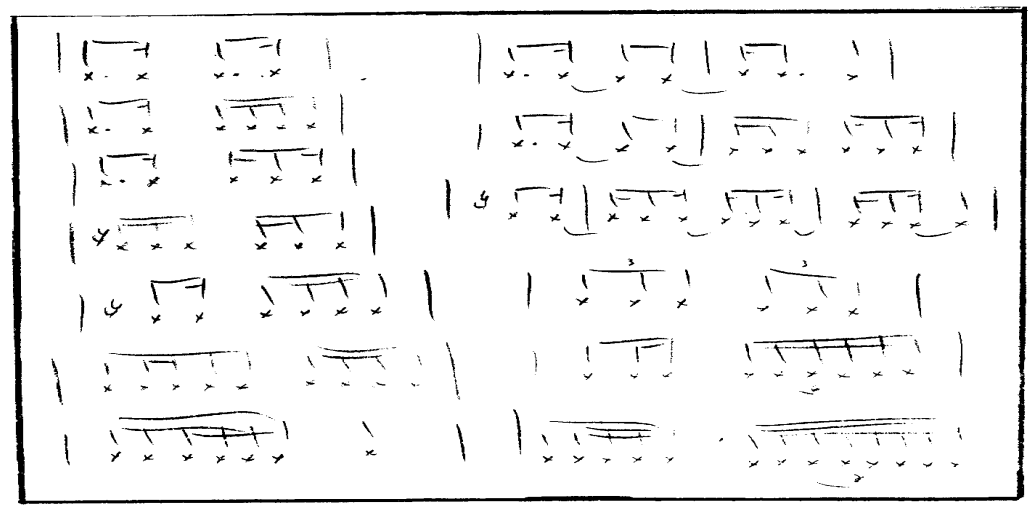

Fonte: TABORDA (1995, p. 79).

\footnotetext{
${ }^{22}$ Pellegrini (2005, p. 130) identifica o violão tamborim na composição Corra e Olhe o Céu (Cartola).
} 


\subsection{Raphael Rabello: o violão de sete cordas solista}

Raphael Rabello (1962-1995) provém de uma família musical. Seu avô paterno foi responsável por iniciar grande parte da família na música, seja pelo violão ou pelo coral de suas irmãs. Aos 12 anos de idade, Rabello teve aulas com Meira (1909-1982). Nesse período, Rabello estudava o instrumento pelo treinamento auditivo, com destaque para os dois volumes dos Choros Imortais (1964 e 1965) $(\text { BORGES, 2008) })^{23}$.

Aos 14 anos de idade, Raphael passou a integrar Os Carioquinhas ${ }^{24}$. Trata-se do seu primeiro grupo de choro, que gravou um único LP intitulado Os Carioquinhas no Choro (Som Livre, 1977). Após a dissolução do grupo, Radamés Gnattali (1906-1988) contou com a participação de alguns integrantes para formar a Camerata Carioca ${ }^{25}$ no fim da década de 1970. Após excursionar por diversos países nas décadas de 1980, Raphael Rabello recebeu diversos prêmios e gravou discos com renomados músicos brasileiros. Em 1991, Raphael registrou um álbum no qual toca o violão de seis cordas, enquanto Dino Sete Cordas toca o violão de sete cordas.

Para analisar a relação entre o violão de sete cordas de Raphael Rabello, sua obra pode ser dividida em duas fases (BORGES, 2008). A primeira consiste na clara influência dos acompanhamentos de Dino na forma de tocar de Rabello, enquanto a segunda fase revela sua atuação como solista. A relação do violão de Dino e Rabello está documentada em entrevistas nas quais ambos declaram influência recíproca (TABORDA, 1995, p. 69).

Com relação aos aspectos técnicos da primeira fase, Luciana Rabello (entrevista concedida, 2008) ressalta que a baixaria ascendente não era comum nos acompanhamentos de choro, mas foi bastante desenvolvida por Raphael Rabello. Conforme demonstrado, Dino utilizava baixarias até mesmo em fusas, mas não era comum a utilização de baixaria ascendente de forma virtuosa. No álbum Chorando de Verdade (Kuarup, 1987), por exemplo, Rabello utiliza baixarias em fusas na

\footnotetext{
${ }^{23}$ Esse registro fonográfico contou com o acompanhamento do Regional do Canhoto.

${ }^{24} \mathrm{O}$ grupo era formado por Luciana Rabello (cavaquinho), Maurício Carrilho (violáo), Raphael Rabello (violão de sete cordas), Paulo Magalhães Alves (bandolim), Celso Alves da Cruz (clarinete), Celso José da Silva (pandeiro), Mário Florêncio Nunes (percussão) e Téo de Oliveira (arranjador).

${ }^{25}$ O grupo era formado por Luciana Rabello (cavaquinho), Joel Nascimento (bandolim), Maurício Carrilho e João Pedro Borges (violôes de seis cordas), Raphael Rabello (violáo de sete cordas) e Celsinho Silva (percussão). Turíbio Santos (entrevista concedida, 2008) diz que João Pedro Borges ensinava música clássica e teoria musical para Raphael Rabello após os concertos das turnês.
} 
música $E^{\prime}$ do que há (Luis Americano), tanto em movimento ascendente quanto descendente, de acordo com a Figura 9:

FIGURA 9 - É do que há (Luiz Americano): Baixaria virtuosística de Rabello em fusas. Compassos 60-63.

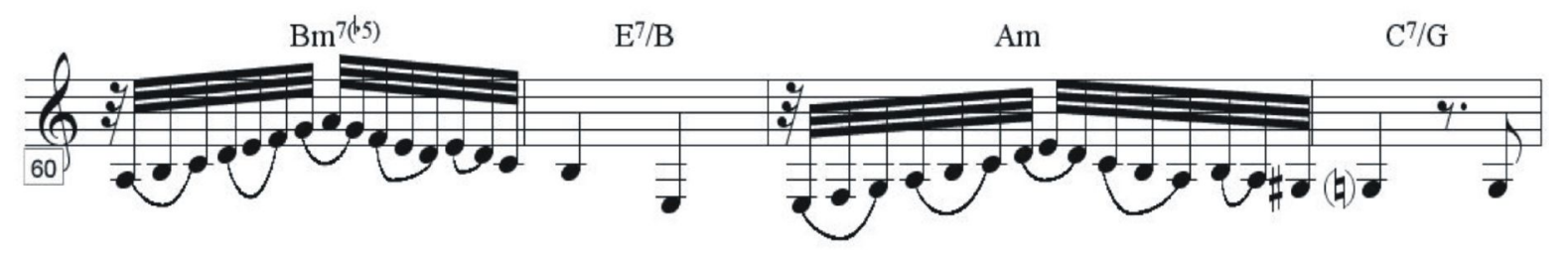

Fonte: BRAGA (2004, p. 69).

Assim como Dino, o violão de acompanhamento de Rabello relaciona-se às conduções rítmicas (ou levadas). Uma das características marcantes dessas conduções rítmicas feitas por Rabello é a variação sobre os acentos no baixo, de forma quase improvisada. A Figura 10 apresenta um desses padróes rítmicos sobre o acorde D6(9) que Rabello costumava utilizar:

FIGURA 10 - Condução rítmica de Raphael Rabello inspirada no samba partido-alto.

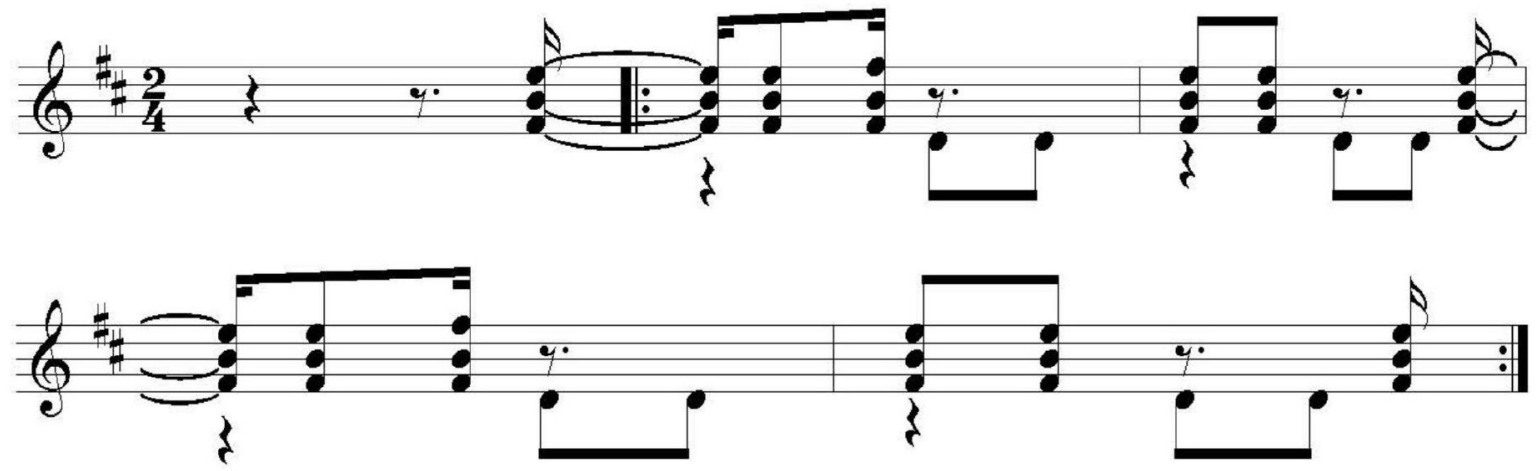

Fonte: BORGES (2019, p. 35).

No álbum Inéditas de Jacob (Eldorado, 1980), é possível observar outras influências de Dino em Rabello. Na música Horas Vagas (Jacob do Bandolim), por exemplo, Rabello executa uma baixaria explorando fusas e sextinas com aproximações cromáticas, conforme Figura 11: 
FIGURA 11 - Baixaria de virada de Raphael Rabello. Compassos 64-67.

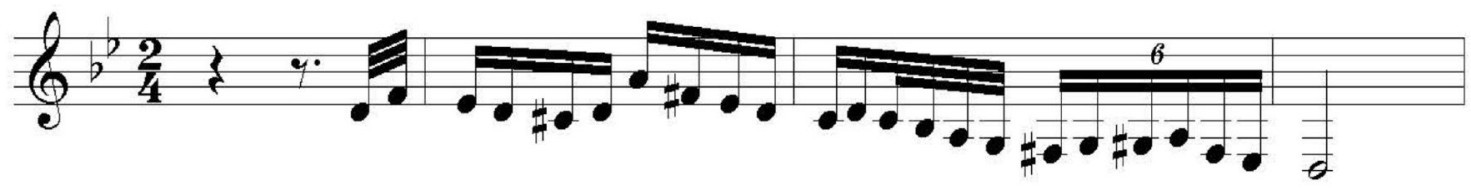

Fonte: BORGES (2008, p. 109).

Uma das caraterísticas mais marcantes do violão de 6 e 7 cordas do choro é o baixo cantante. $\mathrm{O}$ choro Ainda me Recordo ${ }^{26}$ (Pixinguinha) apresenta um longo trecho em baixo cantante na introdução, com base no que Braga define como baixaria de obrigação (2004, p. 35), a qual está consagrada por arranjos ou pela composição original, conforme Figura 12:

FIGURA 12 - Ainda me Recordo (Pixinguinha): baixaria de obrigação antes de iniciar a seção A. Compassos 7-9.

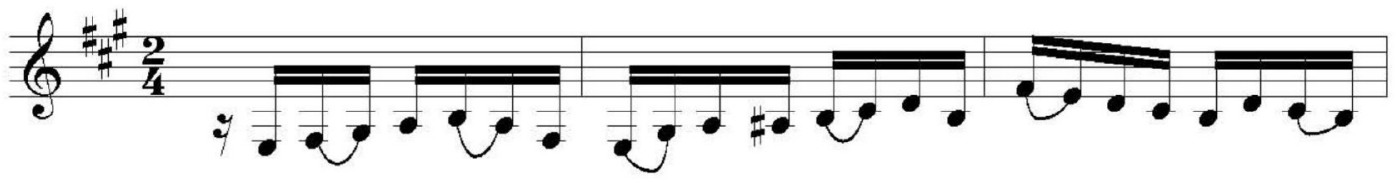

Fonte: BORGES (2008, p. 117).

A segunda fase de Rabello inicia-se a partir do registro fonográfico Rafael Sete Cordas (Polygram, 1982), álbum que contém obras do violão clássico e popular. Entretanto, a segunda fase contempla dois momentos distintos. O primeiro momento refere-se à influência de Dino em Raphael como solista e acompanhador, inclusive sob a perspectiva organológica. O segundo momento da segunda fase consiste no afastamento das características do violão de Dino e na absorção de linguagens não afeitas ao choro (BORGES, 2008). De qualquer forma, a primeira e a segunda fase de Rabello estão inter-relacionadas sob a perspectiva técnica. Luciana Rabello (entrevista concedida, 2008) corrobora essa inter-relação ao dizer que Raphael Rabello acompanhava enquanto solava e solava enquanto acompanhava.

No início da década de 1980, o violonista Luiz Otávio Braga passou a utilizar todas as cordas de náilon em seu violão de sete cordas, diferentemente do violão utilizado por Dino Sete Cordas. Braga (entrevista concedida, 2008) diz que buscava novas possibilidades timbrísticas ao inserir o

\footnotetext{
${ }^{26}$ Marcello Gonçalves (entrevista concedida, 2008) diz que a gravação de Rabello e Dino da música Ainda me Recordo foi determinante para que ele optasse pelo estudo do violão de sete cordas.
} 
violão de sete cordas na Camerata Carioca de Radamés Gnattali, sem a necessidade de trocar de instrumento entre uma música e outra. Raphael passou a adotar essa mesma organologia em seu violão, o que foi decisivo para sua segunda fase.

Para identificar as características do violão do choro, foram selecionadas quatro obras para violão. Duas obras refletem o estilo não tradicional, sendo um arranjo e uma composição de Raphael: Comovida (Guinga) e Pedra do Leme (Raphael Rabello/Toquinho). Duas obras refletem o estilo tradicional, sendo um arranjo e uma composição de Raphael: Praça Sete ${ }^{27}$ (Dino Sete Cordas/Francisco Sá) e Meu Avô (Raphael Rabello).

A música Praça Sete(Dino Sete Cordas/Francisco Sá) está gravada no álbum Rafael Sete Cordas (Polygram, 1982). Essa peça apresenta duas seçốes em Mi maior, cromatismos na linha do baixo cantante, modulação para o V grau (Tabela 3, número 7). Mesmo sendo um CT, Praça Sete apresenta um volteio harmônico (turnround) pouco comum no fim da seção A, conforme Figura 13:

FIGURA 13 - Praça Sete (Dino Sete Cordas) - volteio harmônico da seção A. Compassos 14-16.

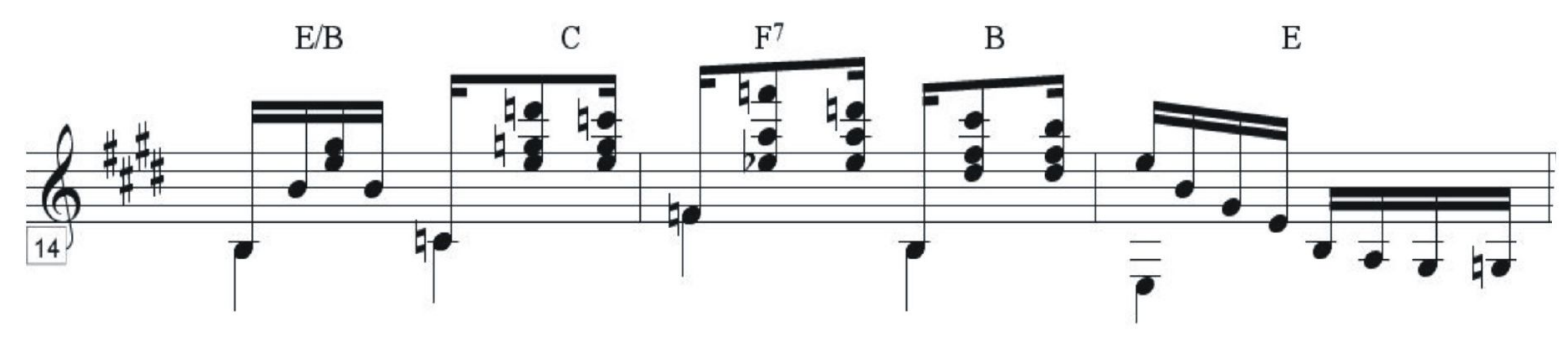

Fonte: BORGES (2008, p. 122).

A música Meu Avô (Raphael Rabello) está gravada no álbum Cry my Guitar (GSP, 2005). Esse choro apresenta diversas características do CT, a exemplo da modulação típica, caminhos convencionais da Árvore Harmônica em tonalidade menor (Figura 1) a exemplo da modulação para o Vm: ${ }^{28}$

\footnotetext{
${ }^{27}$ Marcello Gonçalves (entrevista concedida, 2008) diz que estudou com Dino Sete Cordas na década de 1980. Gonçalves lembra que Dino tocava Praça Sete, mas não costumava tocar violão solo.

${ }^{28}$ A música Meu Avô (também referenciada pelo título de Sinhozinho) segue a modulação típica: seção A (Lá menor), seção B (Dó maior) e seção C (Lá maior).
} 
FIGURA 14 - Meu Avô (Raphael Rabello) - seção A. Compassos 10-17.
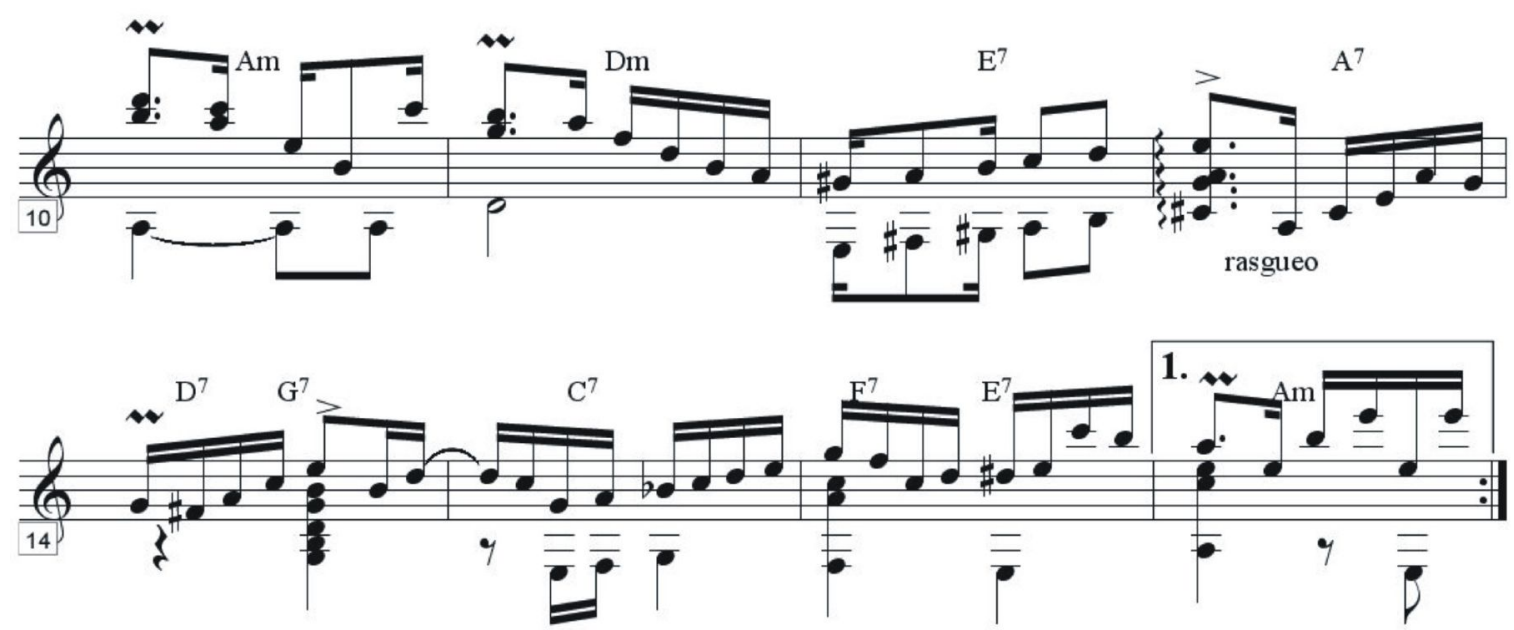

Fonte: BORGES (2008, p. 125).

Radamés Gnattali exerceu grande influência na formação musical de Raphael Rabello. Em duo, Rabello e Gnattali gravaram o álbum Tributo a Garoto (Barclay LP/Funarte, 1982). Esse registro demonstra a inter-relação entre a primeira e segunda fase de Raphael, pois Rabello elabora solos e acompanha no registro fonográfico. Nesse álbum, Gnattali e Rabello gravaram a valsa Desvairada (Garoto), obra interpretada por Rabello em diversos momentos de sua carreira. A articulação de frases em função dos ligados de mão esquerda é bastante evidente em Desvairada. Harmonicamente, há a utilização do intervalo de sexta maior sobre acorde menor, recurso que era utilizado por Dino (BORGES, 2008, p. 40).

O compositor Guinga (entrevista concedida, 2008) assevera que Rabello era um músico resultante da fusão de Dino Sete Cordas e Baden Powell. De outro modo, o violonista brasileiro Fernando de La Rua (entrevista concedida, 2008) compreende o violão de Raphael por um bibridismo associado ao violão brasileiro e flamenco. Essas características flamencas ficam evidentes em certas peças do álbum Todos os Tons (BMG, 1992), como Modinha (Tom Jobim) (BORGES, 2008).

O registro fonográfico Rafael Rabello (Visom, 1988) é emblemático na segunda fase de Raphael em virtude da inter-relação do CT e do CNT em sua obra. Entre as obras brasileiras desse álbum, destaca-se Comovida (Guinga), uma valsa em Mi menor que requer a afinação da sétima corda em Si. 
Guinga (entrevista concedida, 2008) argumenta que a interpretação de Raphael para Comovida fugiu da proposta composicional, em decorrência do violão espanholado. Em contrapartida, Guinga ressalta a genialidade de Raphael, lembrando que a interpretação apresenta inovações técnicas surpreendentes. Guinga salienta também que nunca gravou Comovida em razão de dificuldades técnicas, mas aproveitou os acordes iniciais para compor Catavento e o Girassol, uma canção em parceria com Aldir Blanc. A presença de rasgueos em Comovida denota uma das características do violão espanbolado ressaltadas por Guinga na interpretação de Rabello:

\section{FIGURA 15 - Comovida (Guinga): técnica de rasgueo. Compasso 39.}

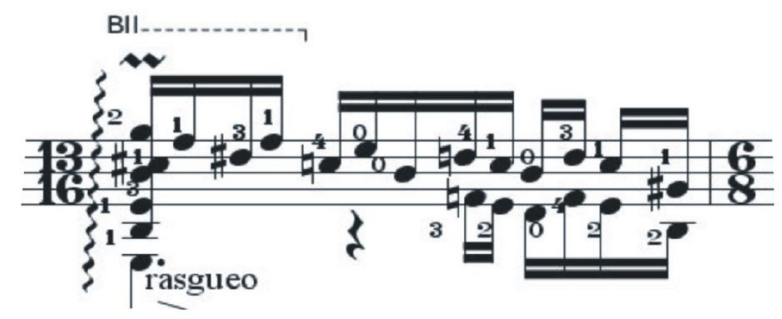

Fonte: BORGES (2008, p. 136).

Assim como a escala de tons inteiros foi observada como elemento não tradicional no violão de Dino Sete Cordas, Rabello utiliza a mesma escala nos compassos finais de Comovida (Guinga):

FIGURA 16 - Comovida (Guinga). Compassos 47-50.
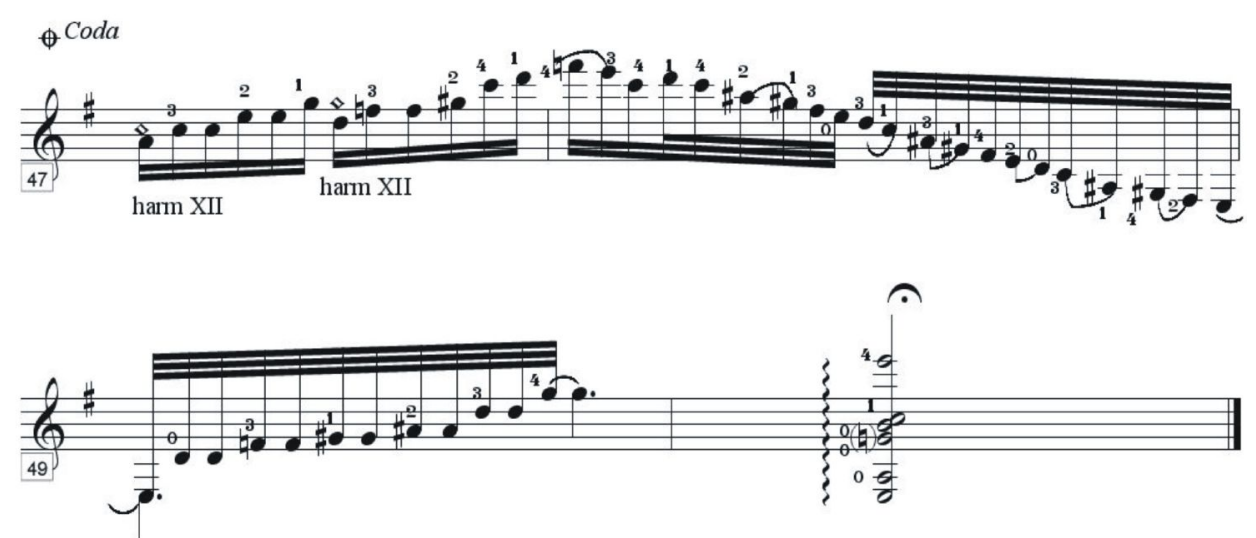

Fonte: (BORGES, 2019, p. 43).

No CD Cry my Guitar (GSP, 2005), destaca-se também Pedra do Leme (Raphael Rabello/Toquinho), uma peça que havia sido gravada no álbum Rafael Rabello(Visom, 1988). Trata- 
se de um CNT, visto que o choro apresenta uma profusão de elementos não tradicionais ao longo de toda a obra, com destaque para o volteio harmônico (turnaround) pouco comum na seção A:

FIGURA 17 - Volteio harmônico de Pedra do Leme (Raphael/Toquinho). Compassos 13-15.

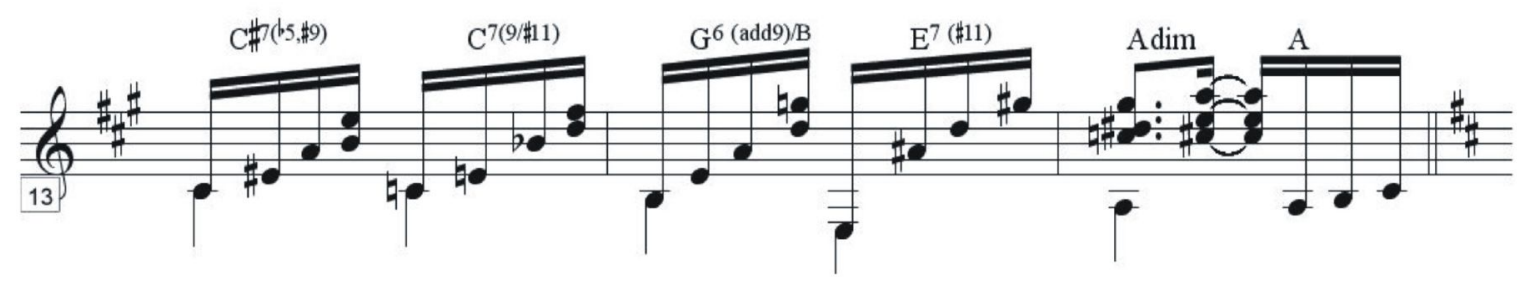

Fonte: (BORGES, 2008, p. 139).

Há uma modulação passageira para Fá\# maior (III maior) na seção B, o que corresponde ao número 6 da Tabela $1:^{29}$

FIGURA 18 - Pedra do Leme (Raphael Rabello/Toquinho): seção B. Compassos 22-27.

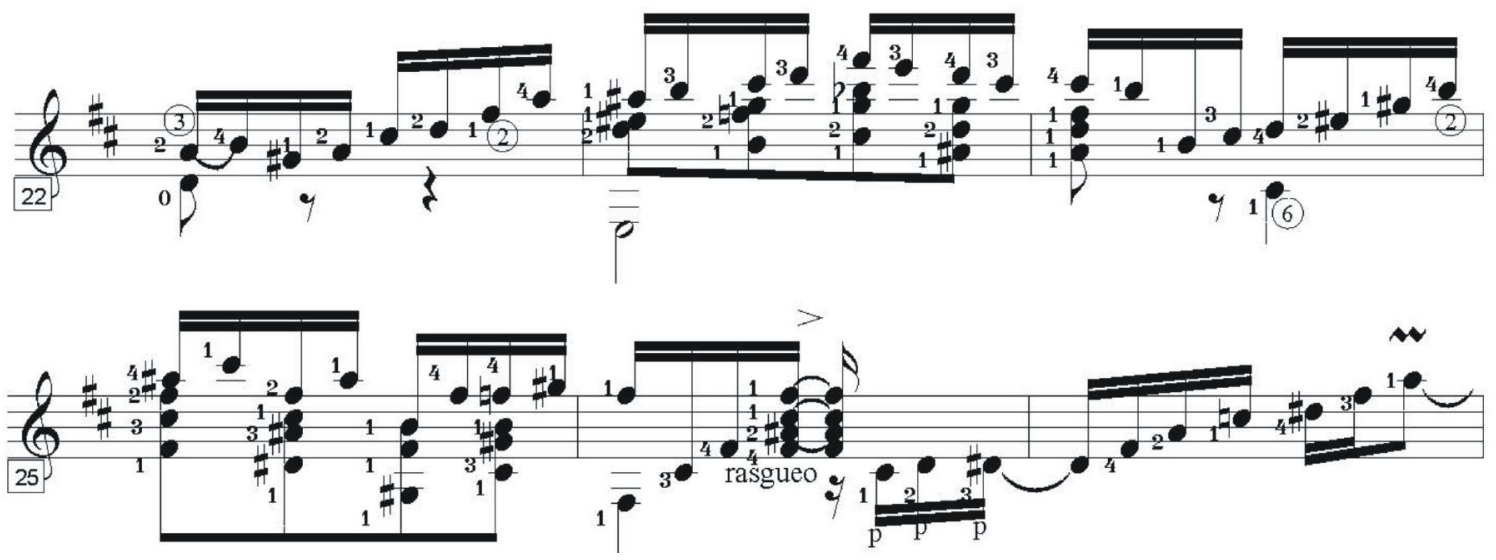

Fonte: BORGES (2008, p. 168).

Na seção C, observa-se a utilização de acordes dominantes com a quarta aumentada (modo lidio b7) por meio do acorde G7(\#11), exercendo a função de sub $V^{7}$ de F\#m7:

\footnotetext{
${ }^{29}$ A modulação passageira para o III grau maior foi identificada em Lamento (Pixinguinha/Vinícius de Moraes), conforme Figura 2.
} 
FIGURA 19- Pedra do Leme (Raphael Rabello/Toquinho): seção C. Compassos 73-79.

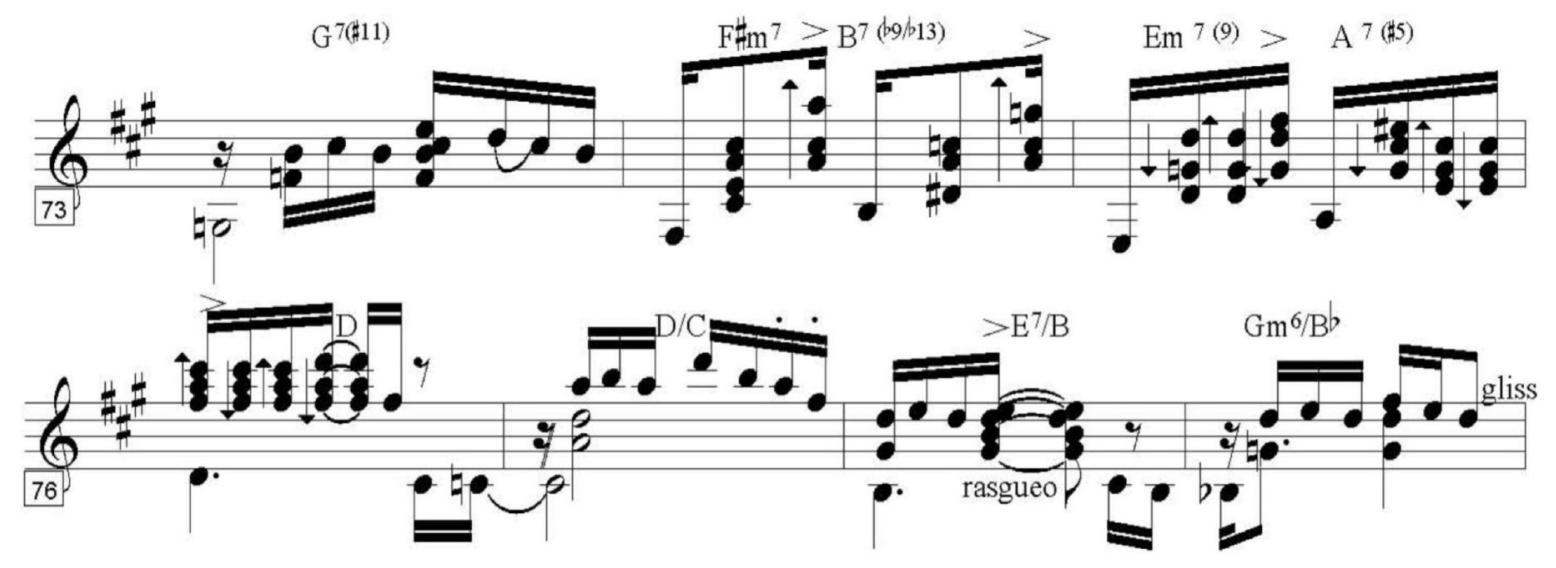

Fonte: BORGES (2008, p. 143)

Ao longo da década de 1980 e parte da década de 1990, Rabello deixou inúmeros registros musicais como solista e acompanhador de diversos instrumentistas. Os álbuns demonstram que a maneira de acompanhar está relacionada à sua maneira de solar, justamente pela técnica das baixarias, cujo elo é o solo de baixaria.

\subsection{Resultados: a união do violão solista e acompanhador}

O conceito de baixaria como contracanto na região grave não se sustenta quando o violão assume a primeira voz, pois há a possibilidade de alcançar também notas agudas. Para sanar esse dilema conceitual, Carneiro (2001, p. 34) utiliza o termo solo de baixaria para referir-se aos momentos em que o instrumento assume a voz principal. A primeira vez em que um solo de baixaria apareceu em um registro fonográfico foi na música Teu Beijo (Mário Álvares), gravada no álbum Primas e Bordões (1962). O solo de baixaria do Dino Sete Cordas foi gravado conforme transcrição da Figura 20: ${ }^{30}$

\footnotetext{
${ }^{30}$ O choro Teu Beijo segue a modulação típica: seção A (Sol), seção B (Mi menor) e seção C (Dó).
} 
FIGURA 20 - Teu Beijo (Mário Álvares): solo de baixaria de Dino. Compassos 129-144.
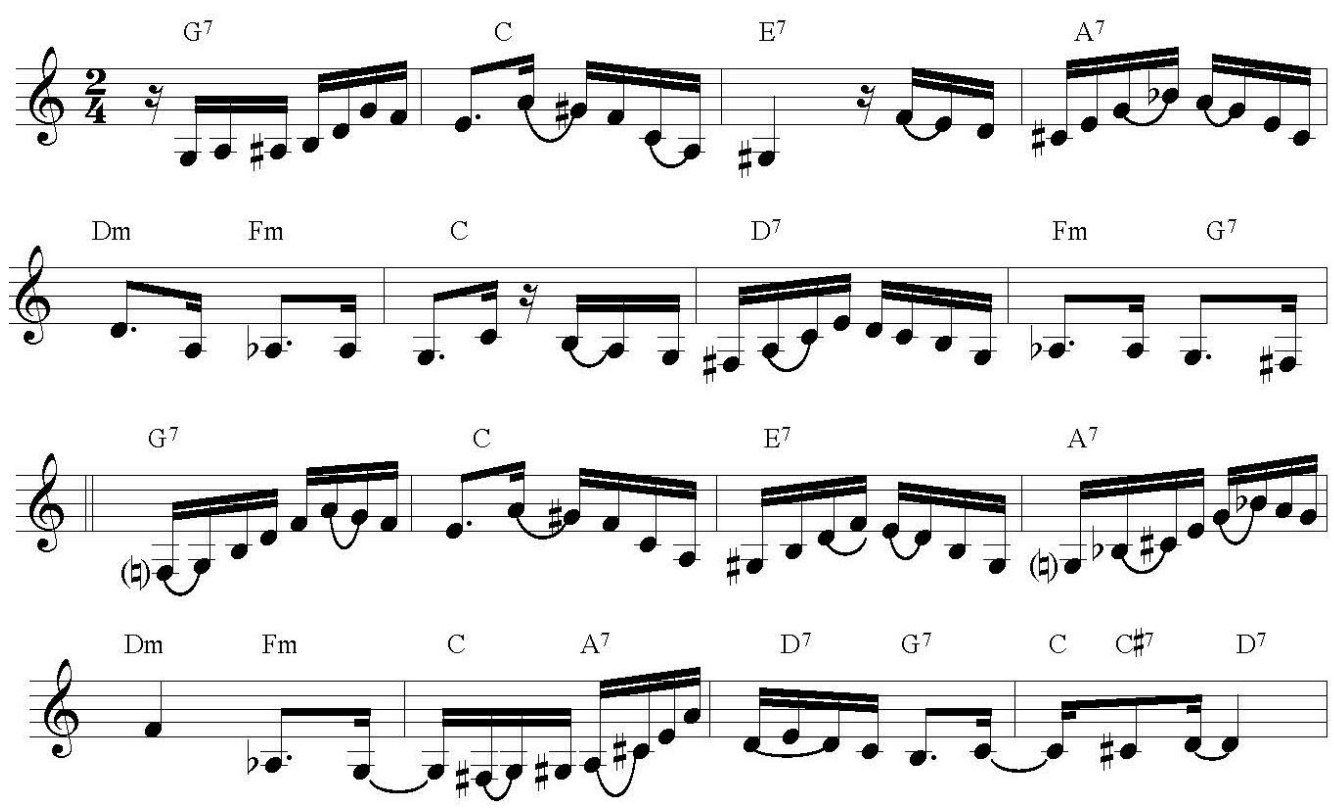

Fonte: BORGES (2008, p. 86).

Ao longo do solo de baixaria, observa-se a utilização de arpejos e aproximações cromáticas. De forma análoga, Dino elaborou um solo de baixaria para o samba Conversa de Botequim (Noel Rosa), gravado no álbum Raphael Rabello E̋ Dino Sete Cordas (Caju Music, 1991). O solo de baixaria é iniciado pela escala descendente de Ré maior com sucessivos encadeamentos de arpejos na seção A:

FIGURA 21 - Conversa de Botequim (Noel Rosa): solo de baixaria de Dino. Compassos 80-96.
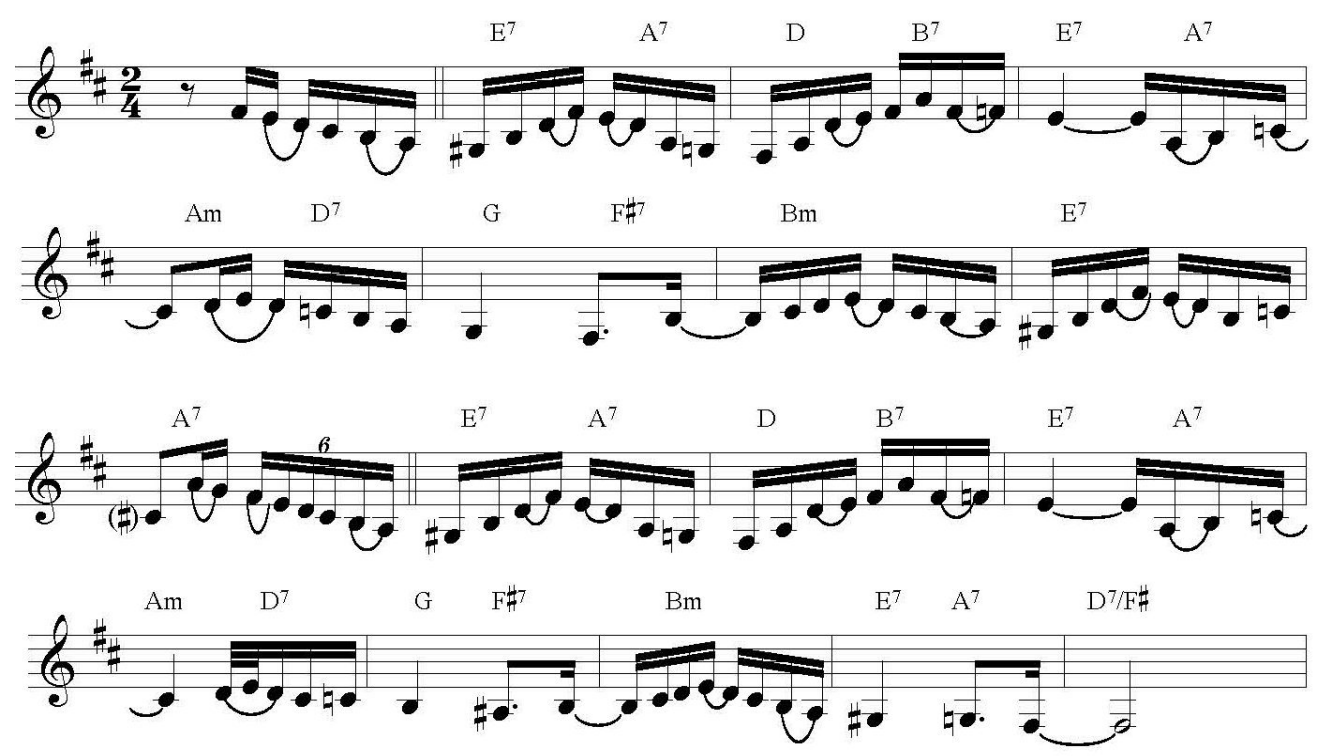

Fonte: BORGES (2008, p. 87). 
O solo de baixaria de Conversa de Botequim apresenta figuras rítmicas análogas às de Teu Beijo, a exemplo da articulação das frases em semicolcheias. Entretanto, Dino utiliza mais arpejos e menos aproximação cromática em Conversa de Botequim. O ponto em comum entre esses dois solos de baixaria é a articulação do fraseado por intermédio de uma técnica de ligados de mão esquerda, cujas características podem ser observadas também nos solos de baixaria de Rabello.

A Figura 22 apresenta um solo de baixaria de Rabello para a música Chorinho na Praia (Jacob do Bandolim), de acordo com a gravação do álbum Inéditas de Jacob (Eldorado, 1980):

FIGURA 22 - Chorinho na Praia (Jacob do Bandolim) solo de baixaria de Rabello.

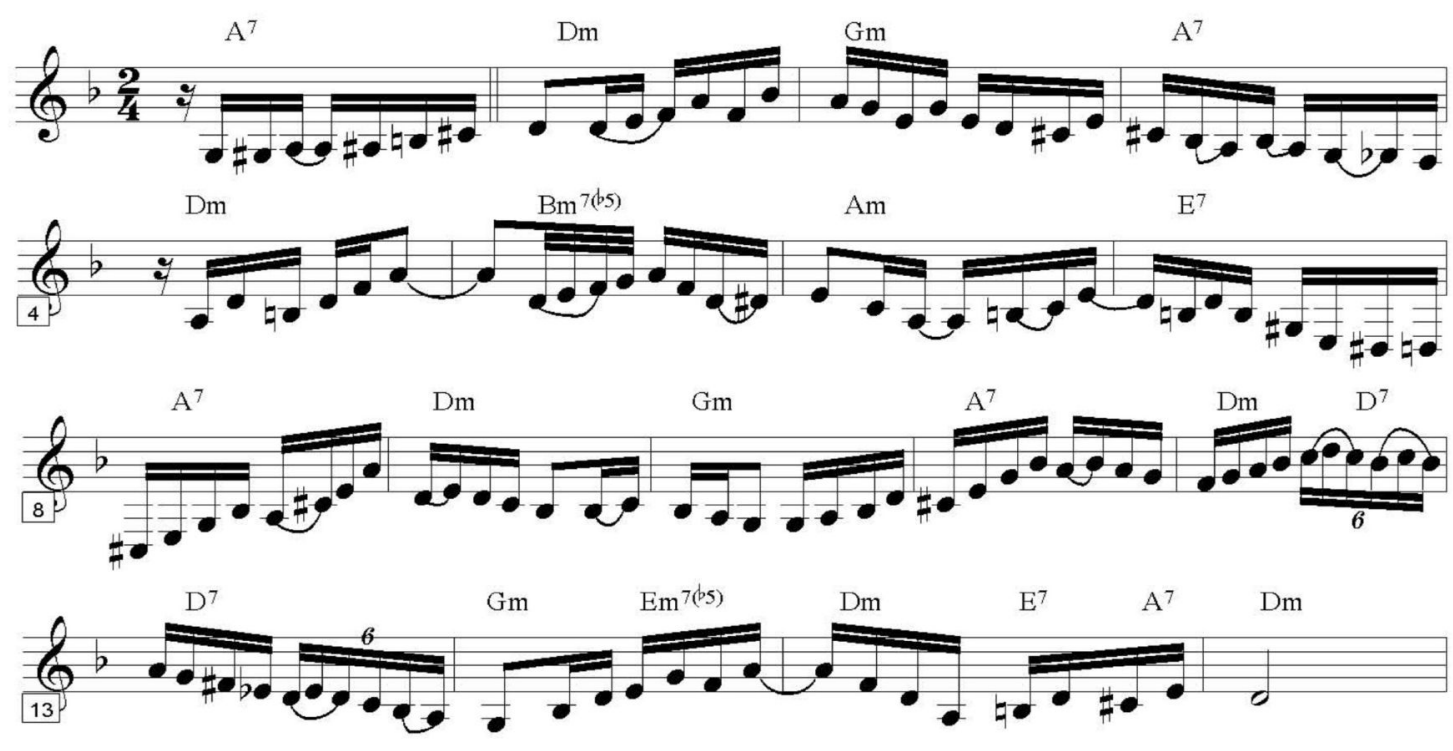

Fonte: BORGES (2008, p. 113).

Alvimar Nunes (2007) analisa o idiomatismo explorado por Raphael no arranjo de Odeon (Caju Music, 1991), tango brasileiro de Ernesto Nazareth. Ao finalizar a seção C de Odeon, Raphael recorre de forma inusitada ao trémolo, técnica amplamente utilizada no violão clássico e no violão flamenco. Nesse arranjo interpretado em um violão com todas as ordens de náilon e sem o auxílio de dedeira no polegar da mão direita, Rabello elabora um solo de baixaria utilizando cordas soltas nas primas e nos bordóes. Entre as influências de Dino nesse arranjo de Rabello, destacam-se as notas de passagem com aproximação cromática, arpejos recorrentes, técnica de apoio do polegar da mão direita e ligados bastante articulados na execução das baixarias. Desse modo, o solo de baixaria demonstrase como o elo entre o violão solista e o violão acompanhador. 
Ao longo de sua carreira, Raphael logrou estabelecer um elo entre o CT e o CNT por meio de técnicas violonísticas oriundas de diversos gêneros e estilos musicais. Além de seu conhecimento profundo sobre o choro, Raphael aplicava recursos musicais não afeitos ao violão do choro, de modo que sua forma singular de tocar é observada na interpretação de obras de vários compositores. É possível observar, nesse contexto, uma relação não conflituosa entre o CT e o CNT, o que sugere uma trajetória não linear para o estudo do choro.

Ao analisar a consolidação do choro como gênero, Verzoni (2000, p. 92) argumenta que editores e produtores de espetáculos precisavam apresentar gêneros que estivessem em voga, de modo que polcas e tangos passaram a ser comercializados com o nome de choros. Assim sendo, não teria o violão sete cordas seguido um caminho análogo nos últimos 20 anos? Alencar Sete Cordas (2007 apud Borges, 2019) argumentou que havia um modismo em torno do violão sete cordas no Brasil, in verbis:

\begin{abstract}
Criou um modismo ruim também! Todo mundo acha que é sete cordas. Aí veio o Yamandu tocar sete cordas. Mas, na realidade, o Yamandu não é um sete cordas. Ele é um violonista seis cordas que, de vez em quando, pega o sete cordas (...) Então, o pessoal fica falando do sete cordas, mas é por isso que acho interessante você perguntar. Não adianta só fazer um "bum bum bum". Então, criou-se um modismo porque todo mundo quer ser um sete cordas. Sabe como é? É um violão de contraponto! Um cara que sabe realmente o sete cordas tem a tendência de saber muita harmonia (BORGES, 2019, p. 95).
\end{abstract}

Alencar Sete Cordas admirava Yamandu, mas atribui o violão de sete cordas à tradição, estabelecendo uma relação indissociável entre o estudo da harmonia e o instrumento no choro. A fala do Alencar Sete Cordas é icônica por demonstrar que as bases sedimentadas por Dino no violão tradicional de sete cordas por volta de 1960 ainda prevalece entre os choróes, tanto do ponto de vista organológico quanto do ponto de vista rítmico e harmônico.

Nas últimas décadas, certas inovações de escalas e acordes no choro são inovações dentro dos sistemas musicais, e não inovaçốes dos sistemas musicais. As contribuiçôes do violão de sete cordas indicam mudança musical quando foram sedimentadas as bases do instrumento com Dino Sete Cordas na década de 1960, visto que as contribuiçôes acompanharam mudanças na própria trajetória estilística do choro em virtude da atuação dos regionais, com destaque para o Conjunto Época de Ouro. Nesse contexto, Taborda (2010) identifica Jacob do Bandolim como um dos pontos estilísticos de inflexão no choro, de modo que Dino foi imprescindível para a consolidação da sonoridade no 
Conjunto Época de Ouro, o que resultou em gravação de registros fonográficos emblemáticos.

Béhague (1973) identificou uma mudança musical do samba no fim da década de 1950, motivada pelo contexto socioeconômico brasileiro do período. As inovações do choro na década de 1960 coadunam-se com a efervescência cultural por meio da qual o Brasil passava no período. Não há dúvidas de que as recentes inovações do violão de sete cordas (após Dino Sete cordas) são relevantes, mas são as contribuições de Dino que configuram mudança musical para o violão de sete cordas no sentido dado por Blacking.

A Tabela 2 sintetiza as características do violão de sete cordas desde o início da tradição do choro no século XX, por intermédio da organologia, técnicas, instrumentação e aspectos harmônicos e melódicos:

TABELA 2 - Síntese dos elementos organológicos e idiomáticos do violão de sete cordas no choro.

\begin{tabular}{|c|c|c|}
\hline Violão de 7 cordas & Estilo Tradicional & Estilo Não tradicional \\
\hline Organologia & $\begin{array}{c}\text { Utilização de cordas em ordens mescladas } \\
\text { (náilon, violoncelo e aço). } \\
\text { Violão típico (BRAGA, 2004) }\end{array}$ & $\begin{array}{l}\text { Utilização de todas as cordas de náilon } \\
\text { (abandono das ordens mescladas) }\end{array}$ \\
\hline Harmonia & $\begin{array}{l}\text { Predominam acordes em tríades, dissonâncias } \\
\text { harmônicas pontuais }\end{array}$ & $\begin{array}{l}\text { Inserção de acordes em tétrades (7M } \\
\text { em acordes maiores, } 7 \mathrm{~m} \text { e } 6 \mathrm{M} \text { em } \\
\text { acordes menores), utilização de acordes } \\
\text { dominantes com \#5, b9 e b13 }\end{array}$ \\
\hline $\begin{array}{c}\text { Melodia } \\
\text { (baixarias) }\end{array}$ & $\begin{array}{l}\text { Predominam escalas diatônicas com } \\
\text { aproximações cromáticas pontuais }\end{array}$ & $\begin{array}{l}\text { Utilização de diversas aproximações } \\
\text { cromáticas, escala de tons inteiros e } \\
\text { escala menor melódica. Concepção } \\
\text { jazzística da teoria da escala de acordes }\end{array}$ \\
\hline Ritmo & $\begin{array}{l}\text { Predominam a marcação de colcheias no } \\
\text { acompanhamento, sem virtuosismo. Utilização } \\
\text { de condução rítmica (ex: violão tamborim) }\end{array}$ & $\begin{array}{c}\text { Inserção de figuras em quiálteras, } \\
\text { sextinas e fusas sob diversas } \\
\text { combinações rítmicas no } \\
\text { acompanhamento, variadas conduções } \\
\text { rítmicas }\end{array}$ \\
\hline $\begin{array}{c}\text { Técnica } \\
\text { violonística }\end{array}$ & $\begin{array}{c}\text { Utilização da dedeira na mão direita. } \\
\text { Predomina a utilização do polegar da mão } \\
\text { direita nas conduções rítmicas. Há pouca } \\
\text { desenvoltura dos dedos indicador (i), médio (m) } \\
\text { e anular (a) }\end{array}$ & $\begin{array}{l}\text { Remoção da dedeira na mão direita. } \\
\text { Ampliação de técnicas violonísticas } \\
\text { com a utilização de trémolo, rasgueos e } \\
\text { outras técnicas não afeitas ao choro } \\
\text { tradicional }\end{array}$ \\
\hline Instrumentação & $\begin{array}{l}\text { Inserção do instrumento nos regionais de choro } \\
\text { como instrumento acompanhador }\end{array}$ & $\begin{array}{l}\text { Participação em pequenas formações } \\
\text { musicais, a exemplo de duos e solo }\end{array}$ \\
\hline
\end{tabular}




\section{Conclusões}

Após breve digressão sobre as danças do choro, este estudo enfatizou a consolidação do choro como gênero na década de 1920, período que coincide com o surgimento do violão de sete cordas no Brasil. Introduzido por China e Tute como um reforço harmônico, o instrumento adquiriu maior relevância com Dino Sete Cordas, sobretudo pelo tratamento dispensado à condução da linha do baixo do instrumento nos regionais de choro por volta de 1960. Na década de 1980, houve outra guinada na história do instrumento no Brasil com as contribuiçóes de Raphael Rabello. Pode-se afirmar, pois, que a história do violão de sete cordas no país acompanhou as transformaçóes estilísticas do choro ao longo do século XX, constituindo uma clara mudança musical (no sentido discutido por Blacking) na década de 1960.

A dicotomia Choro Tradicional (CT) e Choro Não Tradicional (CNT) foi utilizada para analisar estilo neste estudo. Para tanto, recorremos a Blacking como referencial teórico. Foram analisadas as práticas do violão de sete cordas no choro, com base em ferramentas analíticas dos próprios chorões, conforme parâmetros que se aproximam da perspectiva etnomusicológica êmica. As dissonâncias e as eventuais fusões musicais identificadas não resultam necessariamente em produtos híbridos ou modernos, embora ajudem a diferenciar o CT do CNT.

Foi possível identificar elementos não tradicionais tanto no CT quanto nos músicos considerados tradicionais, como Dino Sete Cordas, de maneira que o violão de sete cordas estabeleceu intenso diálogo com diversos gêneros e estilos ao longo do século XX. Essa convivência salutar encontrou um ponto em comum no repertório interpretado pelos chorôes, o que sugere uma trajetória não linear para o estudo choro, visto que as características estilísticas não tradicional e tradicional estão inter-relacionadas até os dias atuais.

$\mathrm{Na}$ década de 1960, Dino consolidou a grande inovação organológica do violão de sete cordas tradicional (ou violão típico), ao combinar cordas de náilon, aço e violoncelo. $\mathrm{Na}$ década de 1980, o violonista Luiz Otávio Braga contribuiu para a segunda inovação organológica do violão de sete cordas, instituindo todas as ordens de náilon. Essa modificação foi incorporada por Rabello no mesmo período, o que exerceu influência sobre o idiomatismo do instrumento, uma vez que as cordas de náilon possibilitaram técnicas oriundas de linguagens musicais não afeitas ao choro. Ao longo do 
século $\mathrm{XX}$, as alteraçôes organológicas e idiomáticas do violão de sete cordas contribuíram para a conformação do estilo, o que encontra respaldo na literatura musicológica conforme discutido.

A obra do Rabello pode ser compreendida por meio de duas fases inter-relacionadas. A primeira fase consiste na consolidação dos acompanhamentos de Dino, considerando a organologia tradicional do violão de sete cordas em ordens mescladas (cordas náilon, aço e violoncelo). A segunda fase tem por base o estilo solista de Rabello em dois momentos. O primeiro caracteriza-se pela clara influência de Dino na obra solista de Rabello. O segundo momento relaciona-se com a expansão de técnicas não afeitas à tradição do choro, o que afasta Rabello do violão de Dino.

O solo de baixaria é o principal ponto em comum entre o violão acompanhador e solista, demonstrando clara relação entre técnica e linguagem, com destaque para a adequada articulação dos ligados de mão esquerda e o tipo de ataque apoiado do polegar de mão direita. No que concerne às conduções rítmicas (ou levadas), foi identificada outra clara semelhança entre Dino e Rabello. Enquanto Dino desenvolveu uma condução rítmica conhecida como violão tamborim, Rabello desenvolveu uma condução rítmica inspirada no samba partido-alto, tornando-se um marco na forma de acompanhar outros músicos.

Sob a perspectiva do idiomatismo, tanto Dino quanto Rabello podem ser compreendidos como os principais responsáveis por ampliar as técnicas do violão de sete cordas no Brasil. Isso permitiu a consolidação de um instrumento virtuosístico e indispensável ao choro. Até mesmo em um violão de sete cordas com todas as ordens de náilon (característica marcante não tradicional do instrumento), é clara a associação entre técnica e linguagem, de modo que o estilo acompanhador de Dino encontrou sua forma solista em Rabello. Para futuros trabalhos, sugere-se a ampliação da curva tonal (Tabela 1) para sistematizar novos caminhos harmônicos utilizados pelos chorôes do CNT.

O violão de sete cordas segue em contínua transformação diante das múltiplas linguagens no choro, o que permite associar a estrutura organológica tradicional com o discurso musical não tradicional e a estrutura organológica não tradicional (ordens de náilon) com o discurso musical tradicional. As bases harmônicas não tradicionais podem ser claramente associadas ao estudo da improvisação do jazz, permitindo a criação de material melódico mais livre e desconectado da melodia principal, tendo por base a teoria da escala de acordes. A estrutura organológica não tradicional, por sua vez, permite a adoção de técnicas oriundas de outras linguagens (como o violão clássico e o 
flamenco), com destaque para a inserção do trémolo e dos rasgueos em arranjos dos choróes. Essa convivência salutar entre diversos estilos no choro demonstra ser a essência do violão de sete cordas no Brasil.

\section{REFERÊNCIAS}

AMORIM, Humberto. Silva Leite e a circulação de peças para guitarra inglesa no Brasil Oitocentista. Anais da Biblioteca Nacional, v. 137-136, p. 301-309, 2019. Disponível em <http://memoria.bn.br/pdf/402630/per402630_2015-2016_135-136.pdf>. Acesso em: 04 mar. 2020 .

AMORIM, Humberto; WOLFF, Daniel. Movimentos do violão no Rio Grande do Sul oitocentista. Revista Vórtex, Curitiba, v. 7, n. 3, p. 1-27, 2019.

ARAGÃO, Paulo. Pixinguinha e a Gênese do Arranjo Musical Brasileiro (1929-1935). Dissertação de Mestrado (Música). Universidade Federal do Estado do Rio de Janeiro, 2001.

BECKER, José Paulo. Brasília, 2008. Entrevista.

BÉHAGUE, Gerard. Bossa \& Bossas: Recent Changes in Brazilian Urban Popular Music. Ethnomusicology, v. 17, n. 2, p. 209-233, 1973.

BLACKING, John. How Musical is Man? Seattle: University of Washington Press, 1973. . Some Problems of Theory and Method in the Study of Musical Change.

Yearbook of the International Folk Music Council, v. 9, p. 1-26, 1977.

BORGES, Luís Fabiano Farias. Transformações Estilisticas do Choro: o Idiomatismo do Violão de Sete Cordas, da Consolidação a Raphael Rabello. Dissertação de Mestrado (Música). Universidade de Brasília, 2008.

As Transformações das Formas Musicais do Choro. In: Anais do IV Encontro da ABET(Associação Brasileira de Etnomusicologia). Universidade Federal de Alagoas. 2008b, p. 60.

Novas Edições Acadêmicas, 2019.

O Violão de Sete Cordas no Brasil: de Tute a Raphael Rabello. Latvia:

BRAGA, Luiz Otávio. O Violão de Sete Cordas. 2o edição. Rio de Janeiro: Lumiar Editora, 2004. Rio de Janeiro, 2008. Entrevista.

BLUME, Friedrich (org.). Die Musik in Geschichte und Gegenwart (Allgemeine Enziklopädie der Musik). Kassel: Bãrenreiter, 1965.

CANCLINI, Néstor García. Culturas bibridas: Estrategias para entrar y salir de la modernidad. Buenos Aires: Paidós SAICF, 2008.

CAZES, Henrique (produção). Beatles 'N' Choro, Volume 2. Projeto idealizado por Renato Russo. CD Produzido por Henrique Cazes, mixado por Rodrigo Vidal. Direção Artística: João Augusto. Rio de Janeiro, Deckdisc, 2003. 
CARNEIRO, Josimar. A Baixaria no Choro. Dissertação de Mestrado (Música). Universidade Federal do Estado do Rio de Janeiro, 2001.

CARRILHO, Maurício. Violão de 7 cordas. Disponível em: $<$ http://ensaios.musicodobrasil.com.br/mauriciocarrilho-violao7cordas.htm>. Acesso em: 10 set. 2008.

CARRILHO, Maurício. Rio de Janeiro, 2008b. Entrevista.

CARVALHO, José Jorge de. Estéticas da Opacidade e da Transparência. Mito, Música e Ritual no Culto Xangô e na Tradição Erudita Ocidental. Anuário Antropológico v. 89, p. 83-116, 1992.

CHEDIAK, Almir. Harmonia e Improvisação. 5a edição revisada. Rio de Janeiro: Lumiar Editora, 1986.

CHORO BRASILEIRO. O melhor do Choro Brasileiro: 60 peças com melodia e cifras: 1o volume. São Paulo: Irmãos Vitale, 1997.

CLÍMACO, Magda de Miranda. Alegres dias choróes: o choro como expressão musical no cotidiano de Brasilia - Anos 1960 - Tempo Presente. 2008. 394 f. Tese (Doutorado em História) - Departamento de História, Universidade de Brasília, Brasília, 2008.

CLÍMACO, Magda de Miranda. Gênero musical Choro e retórica: uma história escrita com sons. In: Simpósio Nacional de História Cultural, 6., 2012, Teresina. Anais... Piauí: UFPI, 2012, p. 1-11.

COSTA, Ricardo Vieira da. Sete Cordas e Flauta: Criação de um Repertório Original Com a Produção de um CD e um Livro de Partituras. Dissertação de Mestrado (Música). Universidade Federal da Bahia, 2015.

ESCOBAR, Carlos Althier de Sousa Lemos (Guinga). Brasília, 2008. Entrevista.

FABBRI, Franco. A Theory of Musical Genres: Two Applications. In: Popular musical perspectives. Amsterdam: Göteborg \& Exeter, 1982.

FARIA, Nelson. A Arte da Improvisação. Rio de Janeiro: Lumiar Editora, 1991.

FERNEDA, Edilson et al. Rumo à Formalização da Teoria das Árvores Harmônicas. Disponível em: http://gsd.ime.usp.br/sbcm/2005/papers/short-13850.pdf. Artigo publicado na USP, 2005.

GALILEA, Carlos. Violão Ibérico. Rio de janeiro: Trem Mineiro Produções Artísticas, 2012.

GIL, A. C. Como elaborar projetos de pesquisas. 4o edição. São Paulo: Editora Atlas, 2002.

GONÇALVES, Marcello. Brasília, 2008. Entrevista.

GUERREIRO, Antônio de Faria. Harmonia Tradicional, Harmonia funcional e Música Popular: uma reflexão motivadora. In: Anais do Congresso da ANPPOM (Associação Nacional de Pesquisa e Pós-graduação em Música), Universidade de Brasília, 2006.

KERNFELD, Barry. Improvisation, Grove Music Online ed. L. Macy. Disponível em: <https://www.oxfordmusiconline.com/grovemusic/view/10.1093/gmo/9781561592630.001.0001 /omo-9781561592630-e-2000215000 > . Acesso em: 23 de agosto de 2020.

KIEFER, Bruno. História da Música Brasileira: dos primórdios ao início do século XX. Porto Alegre: Movimento, 1977. 
KORMAN, Clifford. A Importância de Improvisação na História do Choro. Anais do V Congresso Latino-americano da Associação Internacional para o Estudo da Música Popular. Rio de Janeiro, 2004. Disponível em http://www.hist. puc.cl/iaspm/rio/Anais2004\%20(PDF)/CliffKorman.pdf. Acesso em: Acesso em: 10 set. 2008.

LIMA, Edilson V. de. O Baixo Cantante do Choro: A Herança Viva da Tradição Colonial brasileira? Brasiliana - Revista da Academia Brasileira de Mùsica, número 22, p. 9-16, 2006.

MATEUS, Marlos. O Comportamento Interpretativo do violonista Dino Sete Cordas (1918-2006) em diferentes contextos de atuação no choro. Dissertação de Mestrado (Música Hispana) Facultad de Filosofía y Letras, Universidad de Valladolid, 2017.

MAY, Adam John. The Brazilian seven-string guitar: Traditions, techniques and innovations. Dissertação de Mestrado. Melbourne Conservatorium of Music, 2013.

MOORE Allan F.. Categorical conventions in music discourse: style and genre. Music and Letters, v. 82 n. 3, p.432-442, agosto 2001.

MURRAY, ERIC A. Tradition And Innovation In The Pedagogy Of Brazilian Instrumental Choro. Tese de Doutorado. College of the Arts. Kent State University, 2013.

NETO, Henrique Lima Santos. Elementos do Jazz no Choro: Análise de Elementos Jazzisticos na Composição, Improvisação e Instrumentação Do Choro. Dissertação de Mestrado. Universidade de Aveiro, 2019.

NOBILE, Lucas. Raphael Rabello: o Violão em Erupção. São Paulo: Editora 34 Ltda, 2018.

NUNES, Alvimar Liberato. Interpretação, arranjo e improvisação de Rafael Rabello em Odeon de Ernesto Nazareth. 2007. Dissertação de Mestrado (Música). Universidade Federal de Minas Gerais, 2007.

PALOPOLI, Cibele. Antônimo de "tradicional" é o quê? O surgimento de novas nomenclaturas no contexto do Choro. In: Simpósio Internacional de Musicologia da EMAC/UFG, 8., 2018, Pirenópolis. Anais. Pirenópolis: EMAC/UFG, 2018. p. 1-8.

PALOPOLI, Cibele. Violão velho, Choro novo: processos composicionais de Zé Barbeiro. $262 \mathrm{f}$. Tese (Doutorado em Música) - Escola de Comunicaçóes e Artes da Universidade de São Paulo, 2018.

PELLEGRINI, Remo Tarazona. Análise dos Acompanbamentos de Dino Sete Cordas em Samba e Choro. Dissertação de Mestrado (Música). Universidade Estadual de Campinas, 2005.

RABELLO, Luciana. Rio de Janeiro, 2008. Entrevista.

ROWLAND, D. The nocturne: development of a new style. In: The Cambrigde Companion to Chopin. Edited by Jim Samson. Cambridge University Press. 1992.

RUA, Fernando de La. Brasília, 2008. Entrevista.

SANTOS, Turíbio. Brasília, 2008. Entrevista.

SOARES, José de Alencar (Alencar Sete Cordas). Brasília, 2007. Entrevista.

SILVA NETO, João Fernandes da. Inovação e tradição nas baixarias do choro de Rogério Caetano: pós-modernidade e diálogo com Dino Sete Cordas e Raphael Rabello. Dissertação de Mestrado 
(Música). Universidade Federal de Goiás, 2017.

SOUZA, Grazielle Mariana Louzada de. De Nova Cara O Velho Choro - Choro na contemporaneidade: perspectivas artísticas, sociais e educacionais. Dissertação de Mestrado (Música) Universidade Federal do Mato Grosso, 2012.

TABORDA, Márcia Ermelindo. Dino Sete Cordas e o Acompanhamento de Violão na Música Popular Brasileira. Dissertação de Mestrado (Música). Universidade Federal do Rio de Janeiro, 1995.

. Violão e Identidade Nacional: Rio de Janeiro 1830/1930. Rio de Janeiro, 2004. Tese de doutorado (História). Universidade Federal do Rio de Janeiro, 2004. Publicada em Rio de Janeiro: Civilização Brasileira, 2011.

. O Violão no Rio Oitocentista: um Instrumento na Corte Imperial.

Anais da Biblioteca Nacional, v. 135-136, p. 291-300, 2019. Disponível em: $<$ http://memoria.bn.br/pdf/402630/per402630 2015-2016 135-136.pdf >. Acesso em: 04 ago. 2020. . As Abordagens Estilisticas no Choro Brasileiro (1902-1950). HAOL, núm. 23 (Otoño, 2010) 137-146, 2010.

VALENTE, Paula Veneziano. Transformações do choro no século XXI: estruturas, performancese improvisação. Tese de doutorado (Música). Universidade de São Paulo, 2014.

VERZONI, Marcelo Oliveira. Os Primórdios do "Choro" no Rio de Janeiro. Tese de doutorado (Música). Universidade Federal do Estado do Rio de Janeiro, 2000.

YIN, Robert K. Estudo de caso: planejamento e métodos. 2ª ed. Porto Alegre: Bookman, 2001. ZAGURY, Sheila. O "Neo-choro": os novos grupos de choro e suas re-leituras dos grandes clássicos do estilo. In: Congresso da Associação Nacional de Pesquisa e Pós-Graduação em Música, 15., 2005, Rio de Janeiro. Anais... Rio de Janeiro: UFRJ, 2005. p. 1433-1439. . Os grupos de Choro nos anos 90 no Rio de Janeiro; suas re-leituras dos grandes clássicos e interrelaçôes entre gêneros musicais. 2014. 293 f. Tese (Doutorado em Música) - Instituto de Artes, Campinas, Universidade Estadual de Campinas, 2014.

\section{SOBRE OS AUTORES}

Luís Fabiano Farias Borges é Mestre em música pela UnB. Fabiano Borges atuou em 15 países a convite de universidades, embaixadas, conservatórios e festivais. Ganhador de diversas premiaçóes culturais, Borges possui registros fonográficos e obras editadas no Brasil e exterior. Em 2012, seu trabalho foi citado na Folha de São Paulo como destaque no violão de 7 cordas após Raphael Rabello. No fim de 2015, Borges concluiu o álbum duplo ¡Latinoamérica!, registro fonográfico apresentado em vários palcos tanto no Brasil quanto no exterior. O álbum foi pré-selecionado para o 28o Prêmio da Música Brasileira e contou com resenhas nas revistas Gendai e Classical Guitar Magazine. ORCID: https://orcid.org/0000-0002-1999-846X. E-mail: luis.borges@capes.gov.br 
BORGES, Luís Fabiano Farias; VOLPE, Maria Alice. 0 Violão Sete Cordas no Choro Tradicional e no Choro Não Tradicional. Revista Vórtex, Curitiba, v.8, n.3, p. 1-37, 2020.

Maria Alice Volpe é docente da Universidade Federal do Rio de Janeiro e membro eleito da Academia Brasileira de Música. Doutora $(\mathrm{PhD})$ em Musicologia/Etnomusicologia pela University of Texas-Austin, EUA (orient.: Gerard Béhague). Mestre em Música pela UNESP (orient.: Régis Duprat). Bacharel em Música: Piano (orient.: Beatriz Balzi). Tem contribuído em publicaçôes e eventos científicos nacionais e internacionais. Prêmios: IMS Zurich Steegman Foundation Grant for South-American Scholar (2007); Music \& Letters Trust - Oxford University Press (2008); IMS Tokyo Grant for Latin-American Scholar (2017). Curadora de exposiçốes do Museu Villa-Lobos. Sócia-fundadora da Associação Regional da América Latina e Caribe da International Musicology Society (ARLAC-IMS) e da Associação Brasileira de Teoria e Análise Musical (TeMA). ORCID: https://orcid.org/0000-0003-2122-9616. Email: volpe@musica.ufrj.br 